\title{
Contrasting seasonal changes in total and intense precipitation in the European Alps from 1903 to 2010
}

\author{
Martin Ménégoz ${ }^{1}$, Evgenia Valla ${ }^{1}$, Nicolas C. Jourdain ${ }^{1}$, Juliette Blanchet ${ }^{1}$, Julien Beaumet ${ }^{1}$, Bruno Wilhelm ${ }^{1}$, \\ Hubert Gallée $^{1}$, Xavier Fettweis ${ }^{2}$, Samuel Morin ${ }^{3}$, and Sandrine Anquetin ${ }^{1}$ \\ ${ }^{1}$ Univ. Grenoble Alpes, CNRS, IRD, G-INP, IGE, 38000 Grenoble, France \\ ${ }^{2}$ F. R. S. - FNRS, Laboratory of Climatology, Department of Geography, University of Liège, 4000 Liège, Belgium \\ ${ }^{3}$ Univ. Grenoble Alpes, Université de Toulouse, Météo-France, CNRS, CNRM, Centre d'Études de la Neige, \\ 38000 Grenoble, France
}

Correspondence: Martin Ménégoz (martin.menegoz@univ-grenoble-alpes.fr)

Received: 20 December 2019 - Discussion started: 20 January 2020

Revised: 31 July 2020 - Accepted: 21 September 2020 - Published: 16 November 2020

\begin{abstract}
Changes in precipitation over the European Alps are investigated with the regional climate model MAR (Modèle Atmosphérique Régional) applied with a $7 \mathrm{~km}$ resolution over the period 1903-2010 using the reanalysis ERA$20 \mathrm{C}$ as forcing. A comparison with several observational datasets demonstrates that the model is able to reproduce the climatology as well as both the interannual variability and the seasonal cycle of precipitation over the European Alps. The relatively high resolution allows us to estimate precipitation at high elevations. The vertical gradient of precipitation simulated by MAR over the European Alps reaches $33 \% \mathrm{~km}^{-1}\left(1.21 \mathrm{~mm} \mathrm{~d}^{-1} \mathrm{~km}^{-1}\right)$ in summer and $38 \% \mathrm{~km}^{-1}\left(1.15 \mathrm{~mm} \mathrm{~d}^{-1} \mathrm{~km}^{-1}\right)$ in winter, on average, over 1971-2008 and shows a large spatial variability. A significant $(p$ value $<0.05$ ) increase in mean winter precipitation is simulated in the northwestern Alps over 1903-2010, with changes typically reaching $20 \%$ to $40 \%$ per century. This increase is mainly explained by a stronger simple daily intensity index (SDII) and is associated with less-frequent but longer wet spells. A general drying is found in summer over the same period, exceeding $20 \%$ to $30 \%$ per century in the western plains and $40 \%$ to $50 \%$ per century in the southern plains surrounding the Alps but remaining much smaller $(<10 \%)$ and not significant above $1500 \mathrm{~m}$ a.s.l. Below this level, the summer drying is explained by a reduction in the number of wet days, reaching $20 \%$ per century over the northwestern part of the Alps and $30 \%$ to $50 \%$ per century in the southern part of the Alps. It is associated with shorter but more-frequent wet spells. The centennial trends
\end{abstract}

are modulated over the last decades, with the drying occurring in the plains in winter also affecting high-altitude areas during this season and with a positive trend of autumn precipitation occurring only over the last decades all over the Alps. Maximum daily precipitation index (Rx1day) takes its highest values in autumn in both the western and the eastern parts of the southern Alps, locally reaching 50 to $70 \mathrm{~mm} \mathrm{~d}^{-1}$ on average over 1903-2010. Centennial maxima up to 250 to $300 \mathrm{~mm} \mathrm{~d}^{-1}$ are simulated in the southern Alps, in France and Italy, as well as in the Ticino valley in Switzerland. Over 1903-2010, seasonal Rx1day shows a general and significant increase at the annual timescale and also during the four seasons, reaching local values between $20 \%$ and $40 \%$ per century over large parts of the Alps and the Apennines. Trends of Rx1day are significant ( $p$ value $<0.05$ ) only when considering long time series, typically 50 to 80 years depending on the area considered. Some of these trends are nonetheless significant when computed over 1970-2010, suggesting a recent acceleration of the increase in extreme precipitation, whereas earlier periods with strong precipitation also occurred, in particular during the 1950s and 1960s.

\section{Introduction}

The European Alps are often considered the "water tower" of continental Europe (Beniston et al., 2018), hosting the headwaters of several major European rivers, such as the Rhine, the Danube, the Po and the Rhône rivers. Similar to other 
mountain regions, this stems from both enhanced precipitation rates compared to surrounding lowlands and by the specific role played by glaciers and the mountain snow cover in regulating the local and regional hydrological cycle (Wanner et al., 1997; Viviroli et al., 2008, 2020). The high population density and the presence of strong slopes make these areas particularly prone to natural hazards such as landslides, floods and avalanches, which are strongly connected to meteorological conditions (e.g. Beniston, 2006; Raymond et al., 2019; Evin et al., 2019). There is widespread scientific evidence that significant atmospheric warming has occurred and is projected to occur in the European Alps, as a response to anthropogenic forcing (Hock et al., 2019). This warming is estimated to be $1.2^{\circ} \mathrm{C}$ per century over the 20th century (Auer et al., 2007), which is twice as large as global rates (Brunetti et al., 2009; Gobiet et al., 2014). This warming strengthened over the last decades, with values exceeding $0.3^{\circ} \mathrm{C}$ per decade (Rottler et al., 2019). Precipitation changes are more difficult to detect because of (i) the difficulty to observe and simulate this variable in particular over mountainous areas, (ii) their dependance on the large climate internal variability, and (iii) the spatial heterogeneity peculiar to complex-topography areas.

The longest time series of observed precipitation in the European Alps are available in Switzerland and Italy, with station data that have been homogenized over the last 100 to 150 years (i.e. starting from 1900 and even before; Schmidli et al., 2002; Brugnara and Maugeri, 2019). Such a long record is useful to investigate precipitation changes. But station data need to be considered carefully, because the spatiotemporal heterogeneity of the data availability might be a cause of spurious trends (e.g. Masson and Frei, 2016). Interpolation of station data can be used to produce gridded products, commonly used to investigate climate variability. For example, S2M (Durand et al., 2009) and SPAZM (Gottardi et al., 2012) are two reanalyses covering the French Alps, HISTALP ("historical instrumental climatological surface time series of the Greater Alpine Region"; Auer et al., 2007) and EURO4M (European Reanalysis and Observations for Monitoring; Isotta et al., 2014) are reconstructions of the climate of the European Alps, and E-OBS is a dataset commonly used for model verification over Europe (Cornes et al., 2018). General circulation models (GCMs) are also widely used to investigate climate change processes and trends. However, their coarse resolution precludes accurate simulations of small-scale processes typical of mountainous areas, such as those inducing the spatial heterogeneity of precipitation and snow cover. It is, therefore, difficult to study the Alpine climate variability with GCMs (Zubler et al., 2016). Due to their finer resolution $(\sim 25$ to $1 \mathrm{~km})$ and their more detailed parametrization for physical processes (e.g. precipitation microphysics, surface snow scheme), which can be developed and tuned specifically by considering regional geographical features, regional climate models (RCMs) are more adapted to simulate the mountainous climate and can be used to dynamically downscale GCMs or global reanalyses. They have been widely used to simulate the climate in mountainous areas and in particular temperature (Smiatek et al., 2016), daily and subdaily precipitation events (Torma et al., 2015; Pieri et al., 2015), precipitation trends (Giorgi et al., 2016), and snow cover (Steger et al., 2013). A fine resolution is critical to simulate precipitation correctly. By increasing the resolution from 0.44 to $0.11^{\circ}$, Fantini et al. (2018) demonstrated that a RCM better captures the spatial pattern and the seasonal cycle of precipitation as well as its daily intensities and statistics. The improvement of the model performances currently allows researchers to run RCMs at high resolution, typically 1 to $5 \mathrm{~km}$, in non-hydrostatic configurations, resolving the convective processes and allowing an accurate description of the snow cover in mountainous areas (e.g. Ban et al., 2014, 2015; Lüthi et al., 2019; Vionnet et al., 2019). Such a configuration is, however, challenging to run over more than 1 to 2 decades due to computational costs.

Internal climate variability in the North Atlantic basin induces large seasonal to multidecadal variability of precipitation over Europe (Qasmi et al., 2017; Dell'Aquila et al., 2018; Brugnara and Maugeri, 2019). In the European Alps, higher interannual variability is observed in the southern compared to the northern Alpine areas (Efthymiadis et al., 2007). Seasonally, higher interannual variability in winter and autumn compared to other seasons has been reported in this area (Brunetti et al., 2009; Bartolini et al., 2009). Over the last decades, precipitation rates have been declining for any period of the year in the Mediterranean area (Giorgi and Lionello, 2008; Mariotti et al., 2015), which is a signal partly attributed to anthropogenic forcings (Hoerling et al., 2012) and associated with a significant surface drying (Douville and Plazzotta, 2017). Precipitation trends during the last century are more contrasted over the Alps, with a decrease in the southeastern Alps consistent with the drying of the Mediterranean area (Schmidli et al., 2002; Auer et al., 2007; Brugnara and Maugeri, 2019) and an increase in the annual precipitation in the northwestern Alps, mainly driven by a positive and significant trend in winter and at high elevation (Masson and Frei, 2014, 2016). Napoli et al. (2019) suggested that the contrasted trends of precipitation between high mountains and lowlands over the last decades are explained by the aerosol forcing that cools the atmosphere mainly at low elevations since the air quality is better at high elevations. Precipitation trends also show strong seasonal contrasts in the Alps (Pavan et al., 2019). In addition, precipitation trends emerge from the natural variability only when considering long time series, typically 1 century (Schmidli et al., 2002). This result is consistent with previous studies claiming that precipitation rates did not show any significant trend in the Alps when considering shorter periods, as found in Durand et al. (2009) in the French Alps over the period 1958-2002.

Dry spells did not show any clear tendency over the last century in the Alps (Schmidli and Frei, 2005; Brugnara and 
Maugeri, 2019), whereas the length of dry episodes increased in the Mediterranean area (Kuglitsch et al., 2010). On the other hand, Schmidli and Frei (2005) highlighted contrasting seasonal trends of the wet spell duration in the Swiss Alps, with a lengthening in winter and a shortening in summer. Using 104 rain gauge stations in Switzerland, Schmidli and Frei (2005) found an increase in the high quantiles of precipitation by $10 \%$ to $30 \%$ over $1901-2000$, a result evidencing an increase in extreme precipitation in this area, which they relate to global climate change. This finding has been supported by Scherrer et al. (2016), suggesting an increase in both the intensity and the frequency of heavy precipitation events in Switzerland. The intensity of extreme precipitation is often expected to follow a Clausius-Clapeyron (CC) relationship with temperature changes, with a scaling rate surrounding $7 \%{ }^{\circ} \mathrm{C}^{-1}$ (Trenberth et al., 2003). However, different values of $\mathrm{CC}$ scaling rates has been reported in the literature. Focusing on strong precipitation events observed in Switzerland (and regardless of their duration), Molnar et al. (2015) reported super-CC scaling rates between $11 \%{ }^{\circ} \mathrm{C}^{-1}$ and $13 \%{ }^{\circ} \mathrm{C}^{-1}$, partly related to an intensification of convection during the last 30 years. Conversely, Ban et al. (2015) found an increase in extreme precipitation events that asymptotically intensifies following the CC relationship when applying a convection-resolving RCM at $2.2 \mathrm{~km}$ resolution over the European Alps. Using model data over the last 400 years and over the 21 st century, Brönnimann et al. (2018) evidenced a limitation of the available moisture in the atmosphere at the seasonal timescale that limits the increase in heavy precipitation during the summer even with strong warming levels. They pointed out a shift in heavy precipitation events from late summer to early summer and early autumn. Considering the annual maximum of daily precipitation (Rx1day), Brugnara and Maugeri (2019) also found an increase in extreme precipitation in Switzerland over 1890-2017, whereas they could not highlight a clear trend of extreme precipitation in northern Italy, suggesting a non-uniform spatial change in strong precipitation events. The CC scaling rate shows a large spatial variability, in particular because atmospheric circulation patterns may drive heterogenous moisture advection (Molnar et al., 2015) and also because of the potential limitation of moisture availability at the local scale (Brönnimann et al., 2018). Overall, the $\mathrm{CC}$ scaling rate depends on the frequency of the precipitation data considered in the calculation, with higher $\mathrm{CC}$ scaling rates generally found when considering data with high frequencies (e.g. hourly versus daily).

RCMs are limited-area models that can be forced laterally with atmospheric reanalysis, often available only for the last decades, such as the ECMWF reanalyses ERA40 (19582002, Uppala et al., 2005), ERA-Interim (1979-2019, Dee et al., 2011) and ERA5 (1950 onward; Hersbach and Dee, 2016). Recent reanalysis products available for the whole 20th century (e.g. ERA-20C, 1900-2010; Poli et al., 2016) now offer the possibility to apply RCMs over longer pe- riods, although such a reanalysis, assimilating few data, is less reliable than reanalysis built in the satellite era. Most of the observational and modelling data used to investigate climate change in the European Alps generally do not combine a daily resolution, a centennial availability and a fine spatial resolution, precluding investigations of changes in mean and extreme precipitation. This strongly limits the possibility to detect precipitation trends, especially when considering the large internal variability that may overwhelm longterm trends. In this study, daily precipitation variability and changes in the European Alps (referred to as the Alps in the rest of the text) are investigated over the period 1903-2010, using observational datasets as well as the Regional Atmosphere Model (MAR) applied with a resolution of $7 \mathrm{~km}$ and driven by the ERA-20C reanalysis. The material and methods, including a description of MAR and different observational datasets are described in Sect. 2. The model outputs are compared with several observational datasets in Sect. 3. Seasonal and annual trends of precipitation indices are estimated over 1903-2010 in Sect. 4. A discussion associated with the conclusions is presented in Sect. 5.

\section{Material and methods}

\subsection{The regional climate model MAR}

In this section we provide a succinct description of the Regional Atmosphere Model (MAR; http://mar.cnrs.fr/, last access: 12 November 2020), developed at ULiège (Belgium) and IGE (Grenoble). A more detailed description can be found in Gallée and Schayes (1994), Gallée (1995) and Gallée et al. (2001, 2005). MAR is a hydrostatic primitive equation model with a vertical coordinate defined as sigma coordinates. The radiative transfer through the atmosphere uses the radiative scheme of the ECMWF reanalysis (Morcrette, 2002). MAR includes a detailed scheme of clouds microphysics with six prognostic equations for specific humidity, cloud droplet concentration, cloud ice crystals (concentration and number), concentration of precipitating snow particles and rain drops. The convective adjustment is parameterized according to Bechtold et al. (2001). MAR is coupled to the one-dimensional land surface scheme SISVAT (Soil Ice Snow Vegetation Atmosphere Transfer; De Ridder and Schayes, 1997; Gallée et al., 2001) that includes a snow multilayer scheme (Brun et al., 1992 ), including prognostic equations for temperature, mass, water content and snow properties (dendricity, sphericity and size) as well as an ice module (Lefebre et al., 2003). As pointed out in Messager et al. (2006), the physics of MAR can be adjusted to the region of interest and can be used with relatively high resolutions (40 to $7 \mathrm{~km}$; finer resolutions would not be possible when using the hydrostatic configuration). MAR is a limitedarea model that offers the advantage to be able to be forced by most reanalyses (including ERA-20C) or CMIP5/CMIP6 
global model outputs. MAR has been first designed for polar regions (Gallée, 1995), i.e. Antarctica (e.g. Gallée et al., 1996; Naithani et al., 2002; Gallée et al., 2013; Amory et al., 2015; Agosta et al., 2019) and Greenland (Fettweis et al., 2017). It has also been applied over tropical regions (Messager et al., 2004) to investigate the precipitation variability (Gallée, 2004). MAR has also been used to simulate the climate at midlatitudes (e.g. Wyard et al., 2017) and, in particular, to study changes in precipitation over Europe (Doutreloup et al., 2019). It has been applied over various mountainous areas, e.g. Himalaya (Ménégoz et al., 2013), Svalbard (Lang et al., 2015), Kerguelen archipelago (Favier et al., 2016; Verfaillie et al., 2019) and Antarctic peninsula (Datta et al., 2018).

\subsection{MAR configuration}

We used version 3.9.0 of MAR, which is an open-source code available at https://mar.cnrs.fr/ (last access: 12 November 2020). Here, the model was applied over the European Alps with a domain that extends from 42.8 to $48.4^{\circ} \mathrm{N}$ and from 2.5 to $15.2^{\circ} \mathrm{E}$, and it includes $140 \times 90$ grid points at $7 \mathrm{~km}$ horizontal resolution. This domain covers most of the European Alps, except its most eastern part over Austria and Slovenia. With the model physics being affected at the borders by the lateral forcing, a smaller domain is chosen for the analysis, which extends from 43.5 to $48^{\circ} \mathrm{N}$ and from 5 to $13^{\circ} \mathrm{E}$, covering the French, Italian and Swiss Alps, as well as a large part of the Austrian mountains (Fig. 1a). This configuration is based on 24 levels in the atmosphere and 7 levels in the soil, and the snow cover is described with a number of layers varying from 1 to 20 . Here, MAR is laterally forced with the 6-hourly outputs of the ERA-20C reanalysis, and its dynamical and physical schemes are applied with a time step of $60 \mathrm{~s}$. ERA-20C is one of the first reanalyses available from 1900 to 2010, assimilating surface pressure and near-surface winds over the ocean and forced by sea surface temperature (SST) reconstructions (Poli et al., 2016). By assimilating a limited number of variables corresponding to those available relatively homogeneously over 19002010, the ERA-20C reanalysis is expected to be homogeneous over this period, with a limited risk of including spurious trends. However, this reanalysis is probably less accurate than other products also assimilating humidity and temperature in the free troposphere, which is a weakness that could induce model biases also in regional experiments as evidenced by Fettweis et al. (2017) over Greenland. The coarse resolution of ERA-20C $(\sim 125 \mathrm{~km})$ does not allow for a correct description of the atmospheric variables over mountainous areas, which justifies the use of a regional model with higher resolution and advanced physical parameterizations. MAR has already been successfully tested with the ERA20C reanalysis as boundary conditions over Europe (Wyard et al., 2017, 2018). After a spin-up of 2 years, the model in general and the surface component in particular are sup- (a) MAR average precipitation

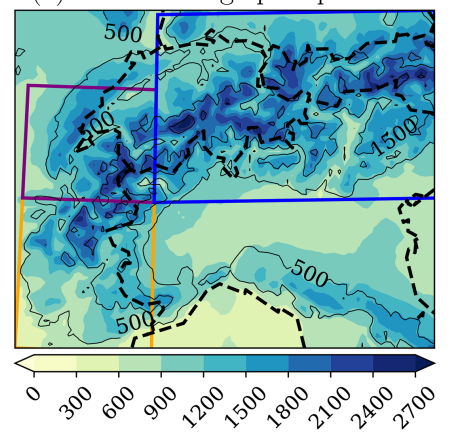

(b) MAR - EURO4M

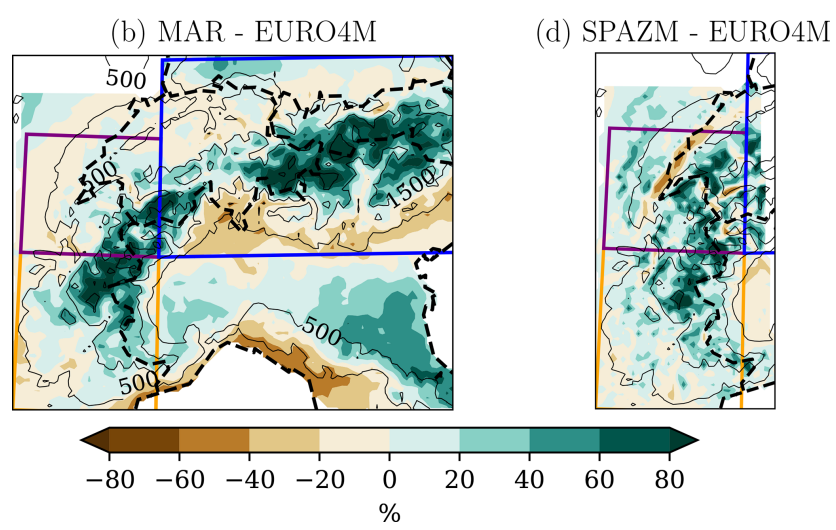

(c) MAR - SPAZM

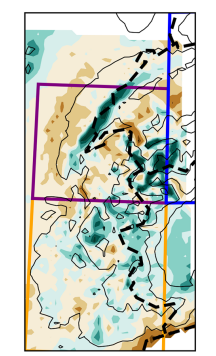

(d) SPAZM - EURO4M
Figure 1. (a) Annual mean of precipitation (TP, $\mathrm{mm} \mathrm{yr}^{-1}$ ) over 1971-2008 in the Alps simulated with MAR applied with a resolution of $7 \mathrm{~km}$ and laterally forced with ERA-20C. The coloured boxes correspond to the southern Alps (SA, orange), the northwestern Alps (NWA, blue) and the northeastern Alps (NEA, purple). Precipitation differences $(\%)$ between (b) the MAR experiment and the SPAZM dataset, (c) the MAR experiment and the EURO4MAPGD observational gridded datasets, and (d) the SPAZM and the EURO4M-APGD datasets. Panels (c) and (d) are shown only for the area where the SPAZM data are available. The $1000 \mathrm{~m}$ spaced black contours show the topography in the $7 \mathrm{~km}$ resolution model, starting from $500 \mathrm{~m}$ a.s.l., and political frontiers are denoted with the black dashed lines. The pattern correlation values between MAR outputs and observational data are 0.59 and 0.63 , respectively, with EURO4M and SPAZM ( $p$ value $<1 \times 10^{-200}$ ).

posed to reach an equilibrium. Therefore, the first 2 years have been excluded from this analysis that hence focuses on the period 1903-2010.

\subsection{Observational datasets}

Observational datasets are used in this study for two objectives: first, a comparison between the model outputs and the different precipitation datasets have been conducted over 1971-2008, a period for which all the datasets are available (Sect. 3). Second, an analysis of the trends of several precipitation indices is described using the MAR experiments and the MeteoSwiss station data available since the beginning of the 20th century (Sect. 4). In addition to the 
MeteoSwiss station data, the following datasets have been considered.

\subsubsection{HISTALP}

The HISTALP ("historical instrumental climatological surface time series") is the first long-term database of meteorological data collected in the European Alps, initiated in the 1990s (Auer and Böhm, 1994) and completed later on (Auer et al., 2007). This dataset is available with a monthly resolution for air temperature at $2 \mathrm{~m}$, surface pressure, precipitation, sunshine duration and cloudiness through two different configurations: a first one including homogenized time series of local measurements, with the first observations available from 1760 for temperature and 1800 for precipitation, and a second one provided as a gridded version. The gridded version, used in our study, is available from 1800 to 2014. Originally available at a $1^{\circ} \times 1^{\circ}$ resolution (Auer et al., 2007), it is now based on a $5^{\prime} \times 5^{\prime}$ resolution (http: //www.zamg.ac.at/histalp/dataset/grid/five_min.php, last access: 12 November 2020).

\subsubsection{EURO4M-APGD}

The Alpine Precipitation Grid Dataset (EURO4M-APGD; Isotta et al., 2014) is a $5 \mathrm{~km} \times 5 \mathrm{~km}$ grid analysis of daily precipitation, extending over the European Alps and covering the period 1971-2008. It is based on rain gauge networks, encompassing more than 8500 stations from Austria, Croatia, France, Germany, Italy, Slovenia and Switzerland. This dataset was developed in the framework of the European Reanalysis and Observations for Monitoring (EURO4M) initiative and is simply named EURO4M hereafter.

\subsubsection{E-OBS}

E-OBS is provided by the ECA\&D (European Climate Assessment \& Dataset) project under the Copernicus Climate Change Service (van den Besselaar et al., 2011). It is a daily gridded dataset over Europe for temperature and precipitation, produced from interpolation of local measurements at two available resolutions: 0.25 and $0.1^{\circ}$ (the highest resolution is used in this study). It is available from 1950 and updated each year, and it is commonly used for model evaluation (e.g. Guillod et al., 2017). Version 19 of E-OBS offers an estimate of the uncertainty related to the interpolation of local observations by providing a 100 -member ensemble for each variable (Cornes et al., 2018).

\subsubsection{S2M}

The S2M reanalysis combines large-scale reanalyses and forecasts with in situ meteorological observations, including precipitation, in order to provide a hourly reanalysis of meteorological conditions in the French Alps, at the scale of massifs with a typical surface area of $1000 \mathrm{~km}^{2}$ within which meteorological conditions are assumed to be homogenous but vary with elevation by steps of $300 \mathrm{~m}$ (Durand et al., 2009). Hence this reanalysis does not use a regular grid but focuses on the elevation dependency of meteorological conditions. A recent version of this open-access reanalysis is now described in Vernay et al. (2019).

\subsubsection{SPAZM}

The SPAZM dataset is a gridded product at a $1 \mathrm{~km}$ resolution for minimum and maximum daily $2 \mathrm{~m}$ temperature and daily precipitation in the French Alps, available over the period 1948-2009 and based on the interpolation of a dense network of rain gauges and temperature sensors from MétéoFrance and the French company Électricité de France (EDF; Gottardi et al., 2012). This dataset is provided with calibration parameters allowing users to reproduce the stream flow observed in the Rhône valley with a hydrological model. These parameters are useful to correct the snowfall rates that are often underestimated in rain gauge measurements. The solid and liquid precipitation has been computed by considering $100 \%$ of solid precipitation below $0{ }^{\circ} \mathrm{C}$ and $100 \%$ of liquid precipitation above $2{ }^{\circ} \mathrm{C}$, considering daily temperature. A linear relationship for the ratio liquid/solid precipitation was applied between 0 and $2{ }^{\circ} \mathrm{C}$. Following the calibration suggested by Picouet (2012), we applied a correction factor for solid precipitation of 1.5 in the northern Alps and 1.3 elsewhere. The northern Alps are defined here as the area located north of Grenoble city $\left(45.1885^{\circ} \mathrm{N}\right)$ and higher than $1000 \mathrm{~m}$ a.s.l. These apparently arbitrary values have been developed and evaluated in the context of hydrological studies (Gouttevin et al., 2017).

An increasing number of climate data based on observational networks, reanalysis product and model experiments covering the European Alps are available, as described in the project EURO4M (Isotta et al., 2014, and http://www. euro4m.eu/datasets.html, last access: 12 November 2020, for recent updates). The number of products in this study has been limited for practical considerations, but obviously, further investigations could be done with other datasets (e.g. ERA5; Hersbach and Dee, 2016; ARCIS Italian observations; Pavan et al., 2019).

\subsection{Statistical analysis and indices}

Mean and trends for the precipitation indices described in Table 1 are considered in this study, most of them selected from those recommended by the World Meteorological Organization (Peterson et al., 2001; http://etccdi.pacificclimate. org/list_27_indices.shtml, last access: 12 November 2020). These indices, for which a full description is shown in Table 1, are the total precipitation amount (annual, TP, or seasonal, STP), the number of wet days (denoted WD), the simple daily intensity index (SDII, i.e. the amount of precipitation during the days with precipitation), the maximum daily 
precipitation (Rx1day), the mean number of wet spells per season (MNWS) and the mean wet spell duration (MWSD). When comparing MAR outputs with observational datasets based on a higher resolution (EURO4M, SPAZM), these ones are linearly interpolated onto the MAR grid. The gridded data are based on regular grids, except the S2M data that are provided with a georeferenced polygon describing the location of each massif. Correlation and root-mean-square error (RMSE) are computed to investigate the differences between datasets. The linear trends are computed with a linear least-square regression, and a two-sided $p$ value is computed to test if the trends are significantly different from zero (Wald test with a $t$ distribution of the test statistic). Mean values and normalized trends (in percentage of the averaged values) are computed annually and seasonally for the precipitation rates and indices in the following sections. The seasons are computed by averaging indices over December-JanuaryFebruary (DJF) for winter, March-April-May (MAM) for spring, June-July-August (JJA) for summer and SeptemberOctober-November (SON) for autumn.

\section{Climatology of the MAR experiment and the observational datasets}

\subsection{Spatial differences}

The total precipitation amount (TP) averaged over 19712008 simulated with MAR is shown in Fig. 1a, with annual mean ranging between 300 and $3000 \mathrm{~mm}$. In a general way, $\mathrm{TP}$ is stronger in the northern than in the southern Alps as expected due to the drier Mediterranean climate in the south. A comparison between the MAR experiment and the EURO4M reanalysis (Fig. 1b) shows a good consistency between these two datasets in the lowlands (i.e. below $500 \mathrm{~m}$ a.s.l.), with positive or negative differences barely exceeding $20 \%$ in these areas, except in the Piedmont-Ticino-Lombardy region and in some parts of the northern Apennines where the model underestimates the strong precipitation rates specific to these medium-elevation areas of the southern Alps. Above $1500 \mathrm{~m}$, this difference is larger with precipitation rates $40 \%$ to $80 \%$ higher in the MAR experiment than in the EURO4M dataset. Such a difference is significant with respect to the interannual standard deviation of precipitation that generally does not exceed $30 \%$ over the domain of application of MAR (Fig. A1). The comparison between MAR and SPAZM (Fig. 1c) shows similar differences in the lowlands as with EURO4M $(\sim 20 \%)$ but a better agreement at high elevation, with differences barely exceeding $40 \%$. Pattern correlation between MAR and EURO4M is 0.59 and reaches 0.63 between MAR and SPAZM, suggesting a slightly better spatial consistency between these last two products. The precipitation rates estimated from SPAZM above $1500 \mathrm{~m}$ a.s.l. are also higher in comparison to those provided by EURO4M (Fig. 1d, differences ranging between $20 \%$ to $80 \%$ ). As snowfall rates in SPAZM have been adjusted to fit the hydrological balance over the French Alps, this comparison suggests that the high precipitation rates simulated with MAR above $1500 \mathrm{~m}$ a.s.l. may be realistic. Overall, TP simulated with MAR is relatively similar to TP estimated from SPAZM and shows stronger values with respect to EURO4M data over the Alps.

\subsection{Vertical gradients}

Vertical gradients of TP simulated with MAR are evidenced in Fig. 2 (as yearly averages, considering both wet and dry days), including also a comparison to the S2M reanalysis and the MeteoSwiss station data. In the MAR experiment, TP varies from 2 to $4 \mathrm{~mm} \mathrm{~d}^{-1}$ at $500 \mathrm{~m}$ a.s.l. and from 3 to $5 \mathrm{~mm} \mathrm{~d}^{-1}$ at $2500 \mathrm{~m}$ a.s.l. in the southern Alps; it varies from 2 to $4 \mathrm{~mm} \mathrm{~d}^{-1}$ at $500 \mathrm{~m}$ a.s.l. and from 3 to $6 \mathrm{~mm} \mathrm{~d}^{-1}$ at $2500 \mathrm{~m}$ a.s.l. in the northern French Alps. The vertical gradient estimated from the S2M dataset is smaller than those simulated by MAR. The large spread in the scatter plots of Fig. $2 a$ and $b$ is explained by the spatial variability of the vertical gradient of precipitation, which is stronger in MAR than in S2M. Based on a comparison with high-resolution numerical weather forecast model and glacier mass balance in mountain glaciers in the French Alps, it has been shown that S2M most likely underestimates high-elevation winter precipitation (above $2000 \mathrm{~m}$ a.s.l.), which lends credence to the higher gradients simulated by MAR (Vionnet et al., 2019). MAR data are compared to the MeteoSwiss station data in Fig. 2c and d. A difference between the two datasets in terms of vertical gradients is found both in winter $\left(14 \% \mathrm{~km}^{-1}\right.$ for the local observations vs. $43 \% \mathrm{~km}^{-1}$ in the MAR data) and in summer $\left(12 \% \mathrm{~km}^{-1}\right.$ for the local observations vs. $20 \% \mathrm{~km}^{-1}$ in the MAR data). These seasonally contrasted differences suggest a possible underestimation of the precipitation rates estimated from rain gauge measurements in relation to snowfall undercatch issues (Kochendorfer et al., 2017). However, the differences found in summer, i.e. a period with reduced snowfall rates, also suggest an overestimation of the precipitation rates at high elevation in the MAR experiment. Nevertheless, it is difficult to accurately quantify the model biases at high-elevation areas because of the scarceness of the observational data above $2000 \mathrm{~m}$ a.s.l., whereas a large number of the MAR grid cells reach an elevation ranging between 2000 and $3000 \mathrm{~m}$ a.s.l. with a spatial resolution of $7 \mathrm{~km}$ (Fig. 2c and d). An underestimation of the precipitation rates in the model versus the station data is also found in summer at intermediate elevation $(500-1500 \mathrm{~m}$, Fig. 2d). This difference appearing only in summer suggests an inability of the convective model scheme, which could induce too much convective mixing. Overall, the vertical gradient of precipitation simulated by MAR over the entire domain of application reaches $38 \% \mathrm{~km}^{-1}\left(1.15 \mathrm{~mm} \mathrm{~d}^{-1} \mathrm{~km}^{-1}\right)$ in winter and $33 \% \mathrm{~km}^{-1}\left(1.21 \mathrm{~mm} \mathrm{~d}^{-1} \mathrm{~km}^{-1}\right)$ in summer (Fig. 2e and f). Overall, the spatial patterns shown in Fig. $2 \mathrm{~g}$ 
Table 1. Annual and seasonal precipitation indices analysed in this study. Precipitation is the sum of solid and liquid precipitation. These definitions follow the recommendation by the World Meteorological Organization (Peterson et al., 2001; http://etccdi.pacificclimate.org/list_ 27_indices.shtml, last access: 12 November 2020).

\begin{tabular}{lll}
\hline Index & Unit & Description \\
\hline TP & $\mathrm{mm} \mathrm{yr}^{-1}$ & Total precipitation amount per year \\
STP & $\mathrm{mm} \mathrm{d}^{-1}$ & Total precipitation amount, including wet and dry days, seasonal or annual \\
WD & $\mathrm{d}$ & Number of wet days $(\geq 1 \mathrm{~mm})$ \\
SDII & $\mathrm{mm} \mathrm{d}^{-1}$ & Simple daily intensity index (TP/WD) \\
Rx1day & $\mathrm{mm} \mathrm{d}^{-1}$ & Maximum daily precipitation, seasonal or annual \\
MNWS & no unit & Mean number of wet spells per season \\
MWSD & $\mathrm{d}$ & Mean wet spell duration, averaged over a season (WD/MNWS) \\
\hline
\end{tabular}

and $\mathrm{h}$ for the MAR experiment and the MeteoSwiss station data suggest that MAR is able to reproduce the seasonal variations of precipitation rates, with large (small) values in summer in the northeastern (southwestern) Alps and an opposite pattern in winter.

\subsection{Interannual variability and seasonal cycle}

The temporal evolution of precipitation and its seasonal cycle over the period 1971-2008 is shown in Fig. 3 for three subregions defined as the southern Alps (SA, 43.5 to $45.5^{\circ} \mathrm{N}$ and 5 to $7.5^{\circ} \mathrm{E}$ ), the northwestern Alps (NWA, 45.5 to $47^{\circ} \mathrm{N}$ and 5 to $7.5^{\circ} \mathrm{E}$ ) and the northeastern Alps (NEA, 45.5 to $48^{\circ} \mathrm{N}$ and 7.5 to $13^{\circ} \mathrm{E}$ ), corresponding respectively to the orange, blue and purple boxes in Fig. 1a. These boxes have been defined according to the data availability of the products used for comparisons as well as regional climatological conditions: SA is largely affected by the Mediterranean dry conditions, NWA precipitation rates are mainly related to western low-pressure systems, and NEA is more typical of a continental climate, with wetter conditions in summer than in winter. Over 1971-2008, precipitation rates estimated from the different datasets (EURO4M, SPAZM, E-OBS, HISTALP) show similar features. They range between 2 and $4 \mathrm{~mm} \mathrm{~d}^{-1}$ in SA and take higher values in NWA and NEA, varying between 3 and $5 \mathrm{~mm} \mathrm{~d}^{-1}$. Table 2 includes the interannual correlations between the different datasets, which take values above 0.8 , except for HISTALP that correlates neither with EURO4M nor with MAR. The correlations between MAR and the observational datasets range between 0.84 and 0.89 , whereas the correlations among these different datasets systematically exceed 0.9 , even reaching 0.99 and 0.97 for EURO4M versus SPAZM in SA and NWA. Such high correlation is probably due to the rain gauge network used to produce these gridded datasets that is partially common between the two products. Overall these correlation values suggest a correct interannual variability in the MAR experiment but less realistic than those estimated from the other observational datasets (except HISTALP). The model bias could be related to both model deficiencies and uncertainties in the ERA-20C reanalysis used as boundary conditions. The dif- ference between the MAR experiment and the observational products is similar in all the datasets, with a RMSE ranging between 0.26 and 1.14. RMSE values computed with HISTALP are comparable to the other ones, evidencing that HISTALP is able to provide an estimation of precipitation similar to the other products, even if the interannual variability is poorly reproduced in this dataset compared to the other ones (low correlation). No clear regional and data-dependent specificity in terms of RMSE is discernable in Table 2. It is worth noting that the uncertainty related to data interpolation in E-OBS (orange dashed lines) encompasses the time series corresponding to the other datasets. Such a large uncertainty is probably related to the low number of observations assimilated in E-OBS over the Alps in comparison with the large number of meteorological stations used to build EURO4M and SPAZM. This points out the large uncertainty of such gridded products in mountainous areas. MAR is closer to SPAZM and EURO4M (smaller RMSE) than to HISTALP and E-OBS (higher RMSE), a finding giving confidence to the realism of the MAR simulation. The different datasets show specific seasonal cycles of precipitation (Fig. 3, bottom), with two maximum values in spring and autumn in SA (Mediterranean climate), one maximum value in summer in NEA (continental climate) and a mix between these two regimes over NWA. Overall, the consistency between the different datasets is better in SA and NEA than over NWA, where more discrepancies among the datasets have been found. The comparison between model experiments and observational datasets gives confidence to the precipitation rates simulated with MAR forced here by ERA20C. Longer simulations are therefore considered in the next section to investigate potential trends over the last century.

\section{Precipitation trends in the Alps over 1903-2010}

\subsection{Mean annual and seasonal precipitation}

No significant trend in precipitation rates is identified on average when considering the three Alpine sub-regions shown in Fig. 3, a finding that could be explained by the short- 
(a) Annual precip, Southern French Alps

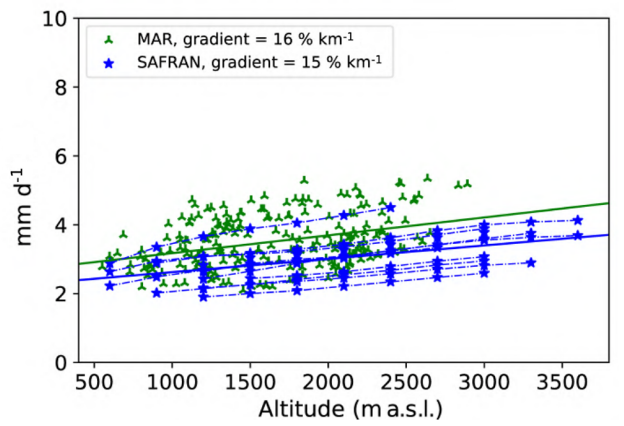

(c) Winter precip, Switzerland

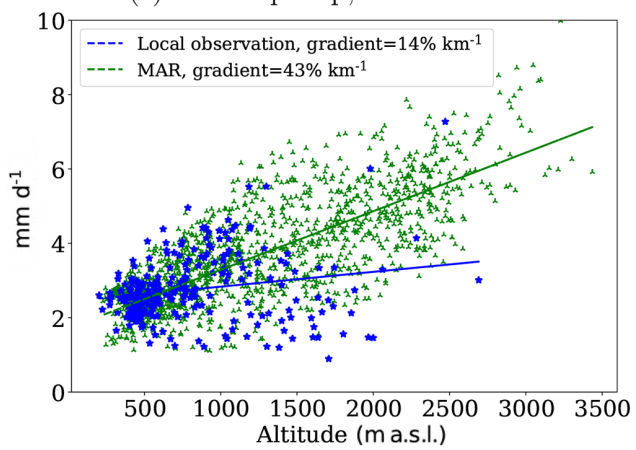

(e) Winter precip, full domain

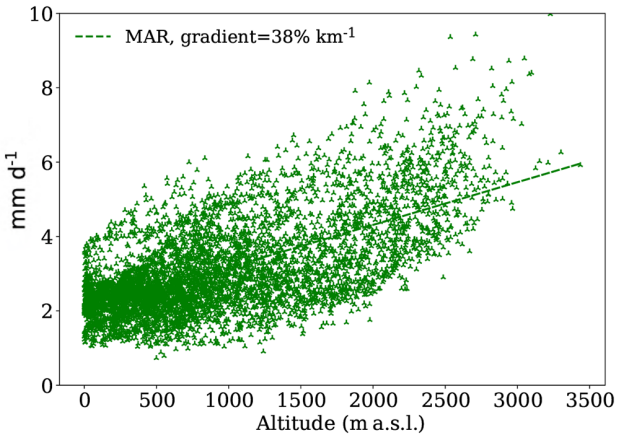

(g) Winter precipitation

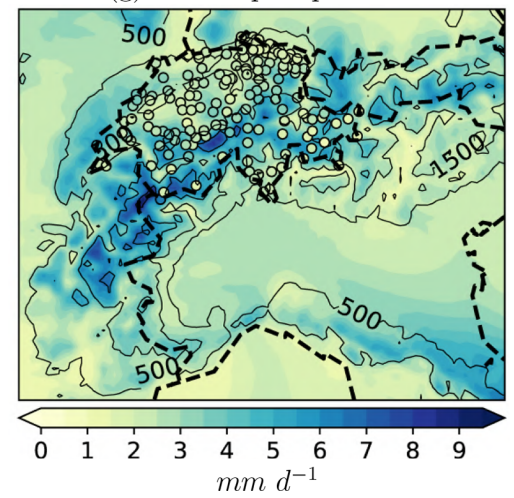

(b) Annual precip, Northern French Alps

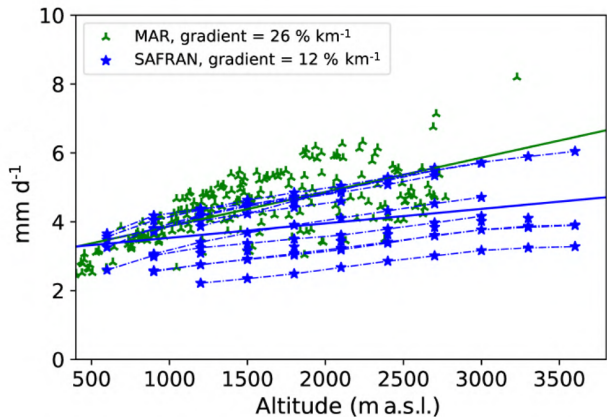

(d) Summer precip, Switzerland

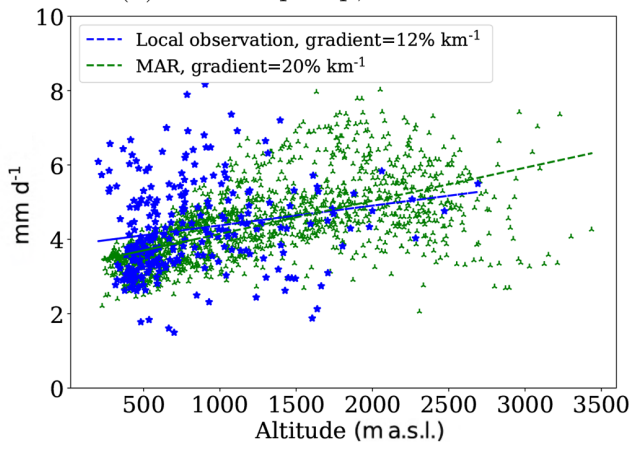

(f) Summer precip, full domain

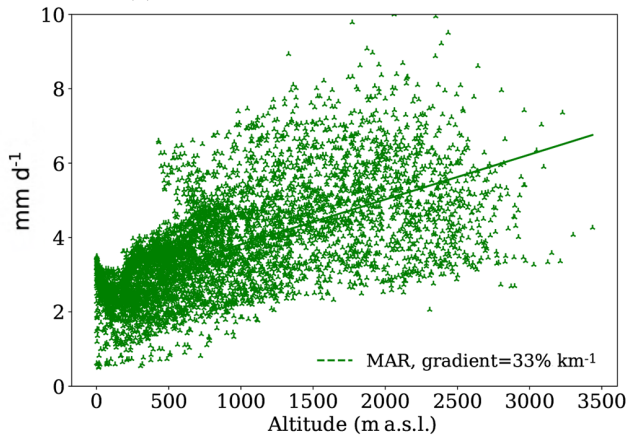

(h) Summer precipitation

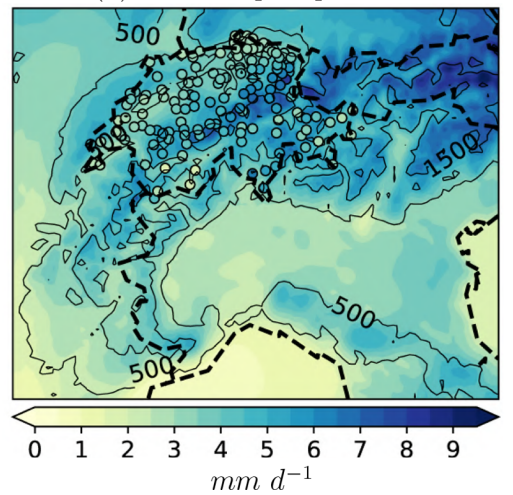

Figure 2. Precipitation (STP) averaged over 1971-2008 simulated by MAR and estimated from reanalyses and observations. Panels (af) show precipitation as a function of the elevation over the southern (a) and the northern (b) French Alps in MAR experiments and S2M reanalysis and estimated over Switzerland from local meteorological stations and from the MAR grid cells covering Switzerland during summer (c) and winter (d). The vertical gradients averaged over the whole model domain are shown for winter (e) and summer (f). STP averaged over 1903-2010 in the MAR experiment (shaded, $\mathrm{mm} \mathrm{d}^{-1}$ ) and observed at MeteoSwiss stations in Switzerland (dots, observations available from the beginning of the 20th century) are shown for summer (g) and winter (h). In (g) and (h), the $1000 \mathrm{~m}$ spaced black contours show the topography with a $7 \mathrm{~km}$ resolution, starting from $500 \mathrm{~m}$ a.s.l., and political frontiers are denoted with the black dashed lines. 

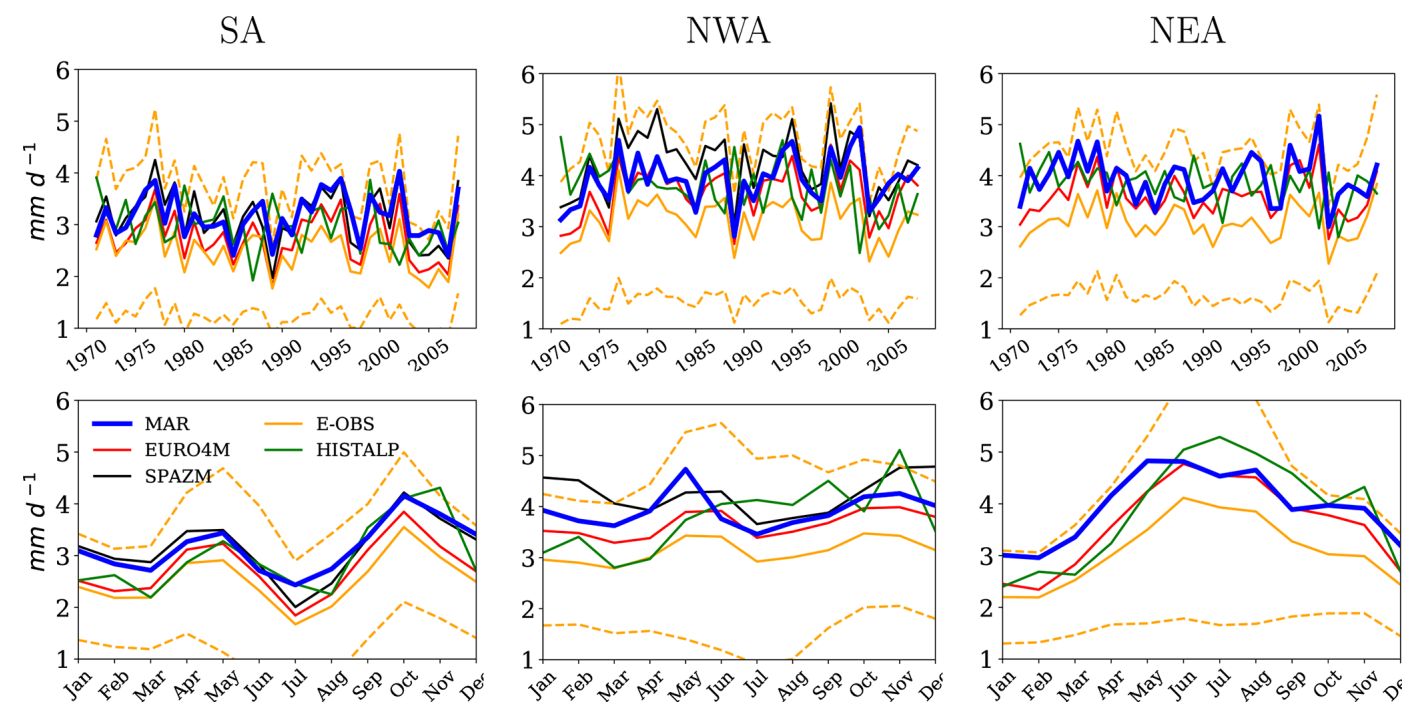

Figure 3. Annual mean precipitation $\left(\mathrm{mm} \mathrm{d}^{-1}\right.$ ) averaged over the southern Alps (SA), the northwestern Alps (NWA) and the northeastern Alps (NEA) over the period 1971-2008 (top row) and corresponding monthly averaged seasonal cycle over the same period (bottom row). The area covered by the SA, NWA and NEA domains can be visualized in Fig. 1. MAR outputs are shown with the observational datasets EURO4M, SPAZM, HISTALP and E-OBS (see text for details). E-OBS (orange solid line) is provided with an estimation of the observational uncertainty (orange dashed lines).

Table 2. Correlation Pearson coefficient computed over 1971-2008 $(C)$ and root-mean-square error (RMSE) between the time series of precipitation data over 1971-2008 for the three different sub-areas described in Fig. 1. All the correlations are significant ( $p$ value $>0.05)$, except those computed with the HISTALP data.

\begin{tabular}{lcll}
\hline & Southern Alps (SA) & Northwestern Alps (NWA) & Northeastern Alps (NEA) \\
\hline MAR - EURO4M & $C=0.89 ; \mathrm{RMSE}=0.46$ & $C=0.88 ; \mathrm{RMSE}=0.37$ & $C=0.85 ; \mathrm{RMSE}=0.41$ \\
MAR - SPAZM & $C=0.87$ RMSE $=0.26$ & $C=0.85 ; \mathrm{RMSE}=0.45$ & - \\
MAR - E-OBS & $C=0.84 ; \mathrm{RMSE}=0.69$ & $C=0.86 ; \mathrm{RMSE}=0.83$ & $C=0.79 ; \mathrm{RMSE}=0.90$ \\
MAR - HISTALP & $C=0.02 ; \mathrm{RMSE}=0.64$ & $C=-0.10 ; \mathrm{RMSE}=0.73$ & $C=-0.22 ; \mathrm{RMSE}=0.66$ \\
EURO4M - SPAZM & $C=0.99 ; \mathrm{RMSE}=0.38$ & $C=0.97 ; \mathrm{RMSE}=0.62$ & - \\
E-OBS - SPAZM & $C=0.93 ; \mathrm{RMSE}=0.63$ & $C=0.95 ; \mathrm{RMSE}=1.14$ & - \\
E-OBS - EURO4M & $C=0.94 ; \mathrm{RMSE}=0.29$ & $C=0.95 ; \mathrm{RMSE}=0.54$ & $C=0.93 ; \mathrm{RMSE}=0.54$ \\
EURO4M - HISTALP & $C=0.03 ; \mathrm{RMSE}=0.68$ & $C=-0.08 ; \mathrm{RMSE}=0.74$ & $C=-0.26 ; \mathrm{RMSE}=0.67$ \\
\hline
\end{tabular}

ness of the time series. The seasonal trends of mean precipitation (STP) are investigated now over longer periods, by considering in Fig. 4 the MAR experiment (shaded) and the MeteoSwiss station data (dotted) over 1903-2010 (left) and over 1958-2010 (right). The MeteoSwiss data are used here because they are available over the period covered by the MAR experiment (i.e. from 1903). Over 1903-2010, trends are contrasted by season and altitude. In winter, there is a general positive trend in precipitation over the Alps (up to $40 \%$ per century), contrasting with a drying simulated in the surrounding plains $(\sim-10 \%$ per century), both in the Po plain and in the Rhône valley (Fig. 4b). In winter, the MAR experiment is consistent with the local observations showing an increase in precipitation over Switzerland, except in the southern part of this country, where some stations show a drying trend. However, when masking the non-significant trends ( $p$ value $>0.05$, Fig. 4a), only the positive trends of precipitation remain over the Alpine mountains, with values ranging between $20 \%$ and $40 \%$ per century in the northern French Alps and in southwestern Switzerland, at an elevation generally higher than $1500 \mathrm{~m}$ a.s.l. The MeteoSwiss data show a significant increase in precipitation at stations located further north in Switzerland, with a magnitude similar to the model values. In summer, a general drying is simulated over the whole model domain (Fig. 4h), with values exceeding $40 \%$ to $50 \%$ per century in the Po and the Rhône valleys. This signal is much less pronounced in the Alpine areas located above $1500 \mathrm{~m}$ a.s.l., where the signal is generally not significant (Fig. 4g). The drying is less pronounced over Switzerland in comparison with the southern Alps. Considering Fig. 4h, a drying and even a slight increase in precipitation $(<10 \%$ per century) is found in the station data 
(a) Winter tr. 1903-2010, non signif masked

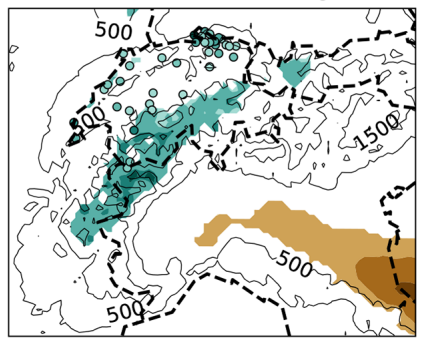

(d) Spring tr. 1903-2010, non signif masked

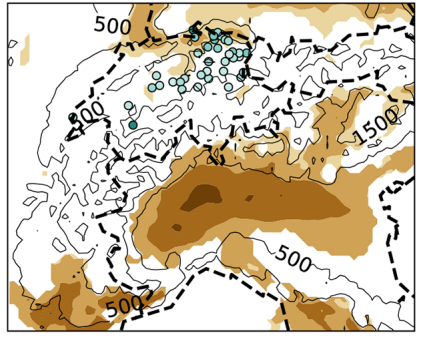

(g) Summer tr. 1903-2010, non signif masked

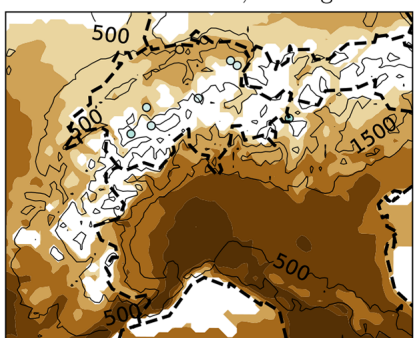

(j) Autumn tr. 1903-2010, non signif masked

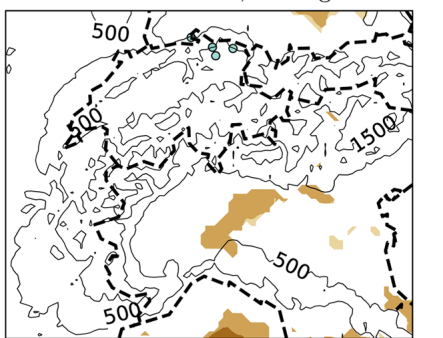

(b) Winter tr. 1903-2010

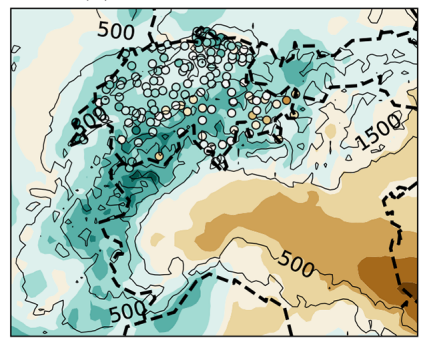

(e) Spring tr. 1903-2010

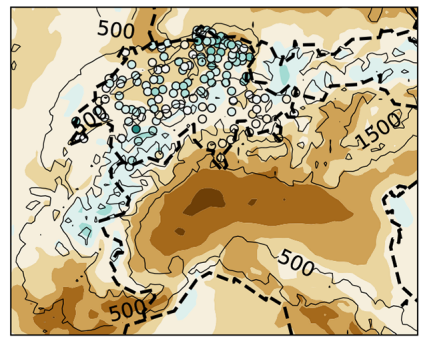

(h) Summer tr. 1903-2010

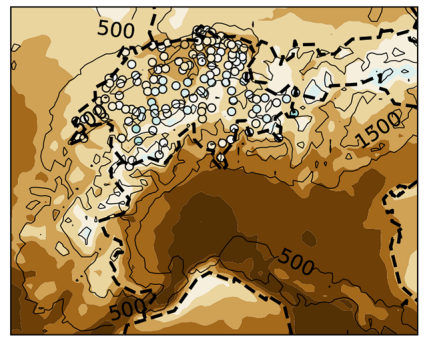

(k) Autumn tr. 1903-2010

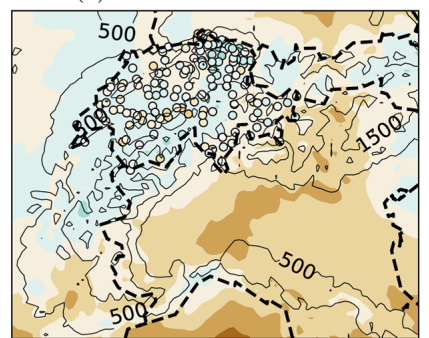

(c) Winter tr. 1958-2010

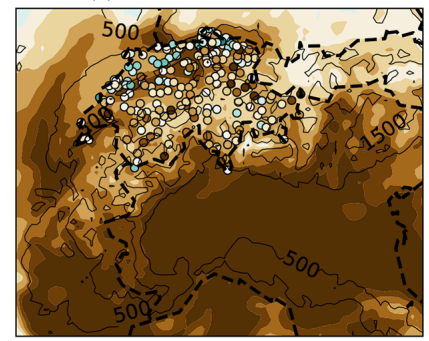

(f) Spring tr. 1958-2010

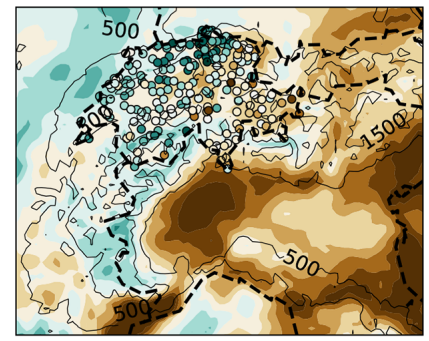

(i) Summer tr. 1958-2010

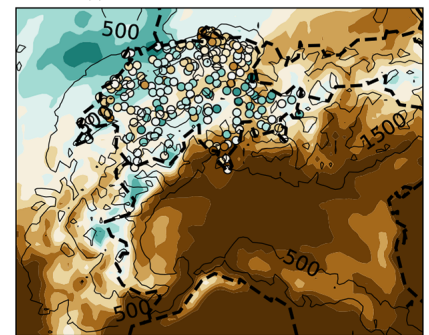

(l) Autumn tr. 1958-2010

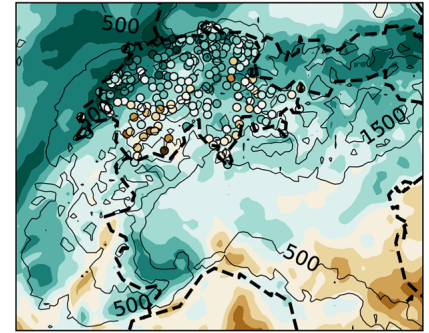

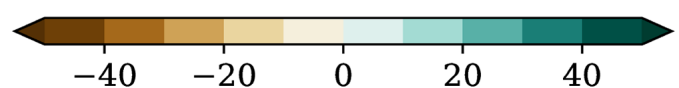

percent per century

Figure 4. Seasonal linear trends (\% per century) of precipitation in winter (a-c), spring (d-f), summer (g-i) and autumn (j-l) over 1903-2010 for (a, b, d, e, $\mathbf{g}, \mathbf{h}, \mathbf{j}, \mathbf{k})$ and over 1958-2010 for (c, f, i, l). The $1000 \mathrm{~m}$ spaced black contours show the topography in the $7 \mathrm{~km}$ resolution model, starting from $500 \mathrm{~m}$ a.s.l., and frontiers are denoted with the black dashed lines. In $(\mathbf{a}, \mathbf{d}, \mathbf{g}, \mathbf{j})$, the trend is masked when its $p$ value is below 0.05 (level of confidence lower than $95 \%$; white areas for the model outputs and station data excluded).

over the mountains of southern Switzerland, whereas a drying is observed in the north of the country (10\% to $20 \%$ per century). The summer trends locally observed in Switzerland are, however, barely significant (Fig. 4g). Spring and autumn trends show intermediate patterns, with a drying pronounced in the plains, and a slight moistening in the mountainous areas (Fig. 4d, e and j, k). The trends simulated and observed during spring and autumn are smaller and barely significant, except in the Po plain where a drying is simulated by MAR and in the north of Switzerland where a moistening is significant at some stations (Fig. 4d-j). Over the more recent period (1958-2010; Fig. 4c, f, i and 1), the only significant signal is the strong drying found in the Po plain $(p$ value $<0.05)$ in winter-spring-summer, when more heterogeneous trends are found in the mountains at the same time (not significant, $p$ value $>0.05$; non-significant trends are not masked in Fig. 4c, f, i and l). The main differences between the trends found over 1902-2010 and 1958-2010 are found in win- 
ter, when the drying occurring in the Po plain is more pronounced and extends until the high-altitude areas during the more recent period (Fig. $4 \mathrm{~b}$ and c). Also, a strong moistening is found in autumn, especially pronounced in the northwestern flank of the Alps. This signal occurred mainly over the last decades (Fig. 4k and 1) but it is generally not significant ( $p$ value $>0.05$, not shown).

The seasonal changes in precipitation simulated with MAR over the Alps are deeply related to the seasonal changes in moisture in the ERA-20C reanalysis used as boundary conditions (Fig. 5). The drying occurring in the Po Plain is related to a drying that occurred over a large part of the Mediterranean area, in particular over the French and the Italian Mediterranean coasts that propagate inland especially during the summer, when southwestern winds transport moisture at the east of the continent (Fig. 5c). During the winter and the autumn, a moistening over Germany, Benelux and the north of France and Switzerland is related to an increase in western moisture fluxes that bring moisture from the Atlantic, in particular over the northern flank of the Alps (Fig. 5a-d). The coarse resolution of ERA-20C does not allow for a fine estimation of the precipitation changes over the Alps, as it can be done with MAR, but conversely, it is shown here that the spatial features of the precipitation changes over the Alps produced with MAR are largely related to the largescale moisture changes driven by the ERA-20C boundary conditions.

\subsection{Wet spells}

Changes in the wet spell features are highlighted in Fig. 6, showing the centennial summer and winter trends of WD (Fig. 6a and b), SDII (Fig. 6c and d), MWSD (Fig. 6e and f) and MNWS (Fig. 6g and h). In winter and over the Alps, the slight increase in WD, ranging between $0 \%$ and $10 \%$ per century, is slightly contributing to the increase in the STP (Fig. 6a), but this one is mainly explained by an increase in SDII by $10 \%$ to $30 \%$ per century (Fig. 6c). These changes are associated with an increase in MWSD by $10 \%$ to $20 \%$ per century (Fig. 6e). Finally, the winter trend in MNWS shows a different pattern from the previous ones (Fig. 6g), with a consistent decrease over the northern Alps and in particular over Switzerland, ranging between $10 \%$ and $20 \%$ per century in both model and observational data. These changes suggest that the precipitation increase found in winter over the Alpine mountains is related to longer, more-intense and less-frequent wet spells. The agreement between the model and the observations is relatively good in winter. In summer, a large part of the drying is explained by a reduction in WD, reaching $10 \%$ to $20 \%$ in the northwestern flank of the Alps, and exceeding $40 \%$ to $50 \%$ per century in the southeastern Alps (Fig. 6b). The SDII shows smaller changes during this season (Fig. 6d) that can be either positive or negative and barely exceed $10 \%$ per century. A general decrease in MWSD is simulated in summer (Fig. 6f), especially pro- nounced over the southeastern flank of the Alps and in the Po plain, which is a signal also found in the observations over Switzerland, albeit with a smaller magnitude. Finally, the model shows a general increase in MNWS (Fig. 6h) in summer, which is particularly strong over the southeastern flank of the Alps. Over Switzerland, this signal is small and not consistent with the observations that show a minor reduction in MNWS. Overall, these results suggest that the decrease in the mean precipitation rates over the Alps in summer is explained by a drastic reduction in WD, with shorter and morefrequent wet spells without any strong change in SDII.

\subsection{Extreme precipitation}

The means and the trends of extreme precipitation rates are described by considering Rx1day seasonally (Fig. 7) and annually (Fig. 8). Extreme precipitation shows contrasted seasonal and spatial climatological patterns (Fig. 7a, c, e and g). In winter and spring, it takes higher values over the southern Alps (both in France and in Italy) than in the northern Alps (Fig. 7a-c). In summer, extreme values are smaller in the western Alps than in the eastern Alps. The most intense events are found in autumn, in both the western and the eastern parts of the southern Alps, with averaged Rx1day values ranging between 50 and $70 \mathrm{~mm} \mathrm{~d}^{-1}$ in many areas (Fig. $7 \mathrm{~g}$ ). Over Switzerland, the climatological pattern of Rxlday is consistent between the model and the observations, except for some local exceptions. In contrast with the trends of mean precipitation (Fig. 4), there is a general increase in Rx1day (Fig. 7b, d, f and h) that occurs during the four seasons and both in the plains and in the mountainous areas. The trend in the seasonal Rx1day over the period 1903-2010 takes values between $0 \%$ and $40 \%$ per century and generally ranges between $20 \%$ and $40 \%$ per century over the Alpine mountain range. Such an increase in percentages suggests strong changes in local extremes, in particular in the regions where strong events are frequent in autumn (50 to $70 \mathrm{~mm} \mathrm{~d}^{-1}$, Fig. $7 \mathrm{~g}$ ). The magnitude of the change in Rx1day is similar between the model and the observations, but the MeteoSwiss station data show more heterogeneous spatial trends, with some locations where the trends can be small and even slightly negative. The mean increase in Rx1day over the model domain reaches $10 \%, 10 \%, 6 \%$ and $13 \%$ per century in winter, spring, summer and autumn, respectively, confirming a general increase in Rx1day for all the seasons.

The climatological mean of the annual Rx1day (Fig. 8a) is dominated by the seasonal Rx1day computed in autumn that shows a similar pattern (Fig. $7 \mathrm{~g}$ ). Centennial Rx1day values (Fig. 8b, maximum Rx1day computed over 1903-2010) show a pattern similar to the annual average of Rx1day. The strongest centennial events are found in the southern Alps, France and Italy, as well as in the Ticino valley in Switzerland, with extreme values locally reaching 250 to $300 \mathrm{~mm} \mathrm{~d}^{-1}$. The annual trends are inspected in Fig. 8c, highlighting a general increase in extreme precipitation. The 

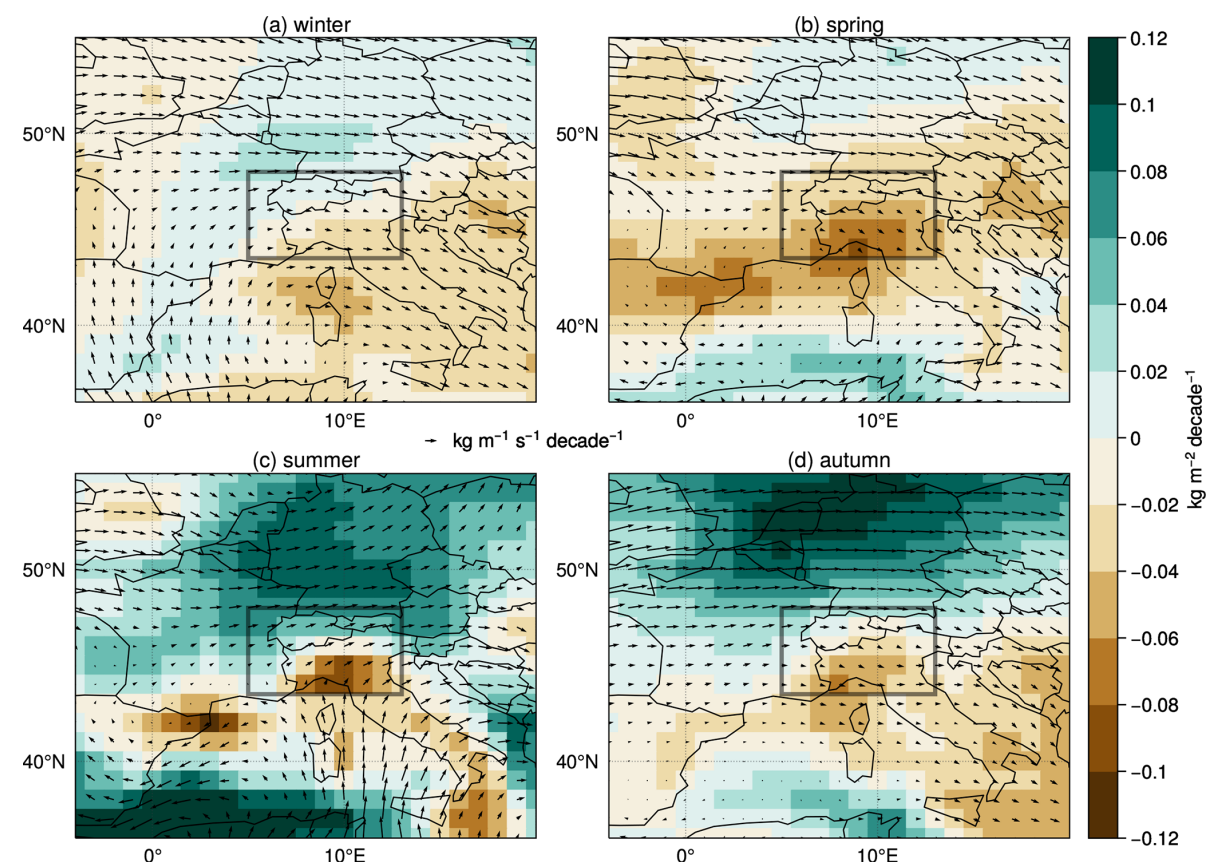

Figure 5. ERA-20C linear trends over 1902-2010 of vertically integrated moisture (shading, $\mathrm{kg} \mathrm{m}^{-2}$ per decade) and vertically integrated moisture flux (arrows, $\mathrm{kg} \mathrm{m}^{-1} \mathrm{~s}^{-1}$ per decade). The rectangle highlights the domain of application of MAR.

significance of this trend is described in Fig. 8d, where nonsignificant trends ( $p$ value $>0.05$ ) are masked. The annual samples considered here are obviously larger than the seasonal samples, allowing us to more efficiently detect significant trends. In that case, a good consistency is found between the model and the MeteoSwiss station, with both of them showing only positive trends, ranging between $20 \%$ and $40 \%$ per century, and covering large parts of the Alps and the Apennines.

\subsection{Statistical significance of the trends}

The large interannual-to-decadal variability of the climate in the Europe-North Atlantic region, in relation to internal climate variability, makes precipitation trends challenging to detect in the Alps. When considering time series over 19712008 , i.e. a relatively short period, there is no clear tendency of the mean precipitation in the Alps (Fig. 3). By computing trends from the beginning of the 20th century, winter increase and summer decrease in mean precipitation emerge from interannual to decadal variability over large areas (Fig. 4). Similarly, the positive trends of the annual $\mathrm{Rx} 1$ day values are significant ( $p$ value $<0.05$ ) over large areas of the Alps, in particular where the trends are positive and strong (i.e. $>10 \%$ per century), whereas all the negative and small trends in both the model data and the MeteoSwiss station data are not significant (Fig. 8d). Figure 8e illustrates the trend of the annual Rx1day, considering the average of the MeteoSwiss data (purple), the model data averaged over Switzerland (blue) and the whole model domain (red). In agreement with the patterns shown in Fig. 8c and d, the mean trend in the annual Rx1day in Fig. 8 is positive for both the model outputs and the observations, reaching 9.43 , 8.74 and $8.40 \mathrm{~mm} \mathrm{~d}^{-1}$ per century, respectively, for the MeteoSwiss data, the model over Switzerland and the model over the whole domain. The vertical bars in Fig. 8e show the length of the time series required to identify a significant trend over the period 1903-2010, starting from 2010 and going back into the past. Starting from 2010, the trends become significant ( $p$ value $<0.05$ ) only when extending the time series backward until 1961, 1932 and 1942 for the MeteoSwiss data, the model integrated over Switzerland and the model integrated over the whole domain, respectively, which correspond to length of time of $\sim 50$ to $\sim 80$ years. We nonetheless see that shorter time series can lead to significant signals as evidenced in Fig. 8f, showing the $p$ value computed to estimate the significant level of the trend. The three curves reach values below 0.05 during the years 1960-1970, highlighting significant trends of Rx1day over 1960-2010 for the observations and over 1970-2010 for the model data.

\subsection{Temperature and precipitation relationship}

The potential relationship between Rx1day and temperature trends is investigated in this section. On average over the MAR domain, the relationship between the Rx1day anomaly and the annual temperature anomaly is significant $\left(p\right.$ value $<0.05$ ) and reaches a positive trend by $3.11 \%{ }^{\circ} \mathrm{C}^{-1}$ (not shown). This value is smaller than the ClausiusClapeyron relationship that reaches in theory $6 \%{ }^{\circ} \mathrm{C}^{-1}-$ 
(a) Winter trend of WD

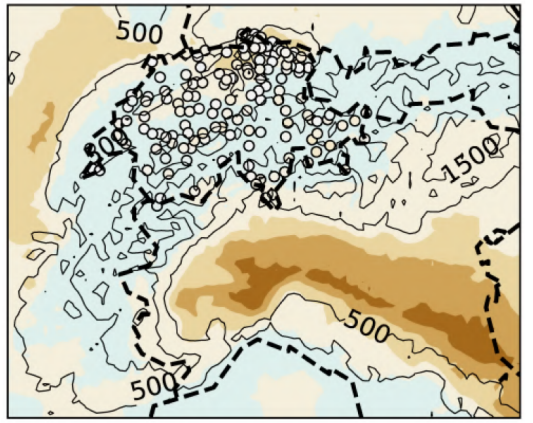

(c) Winter trend of SDII

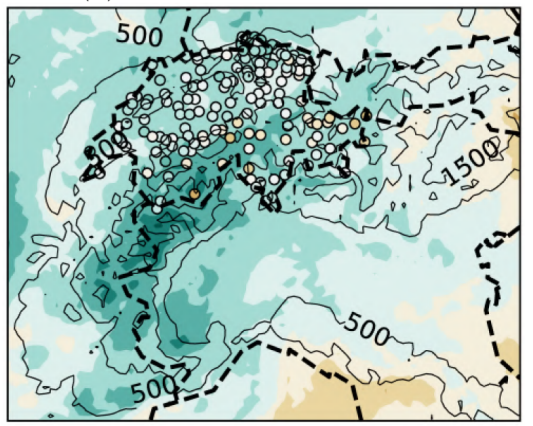

(e) Winter trend of MWSD

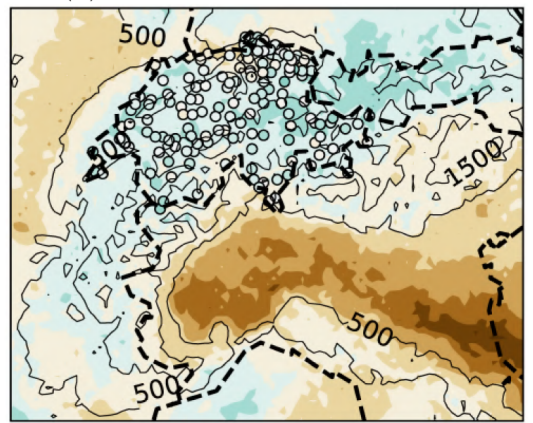

(g) Winter trend of MNWS

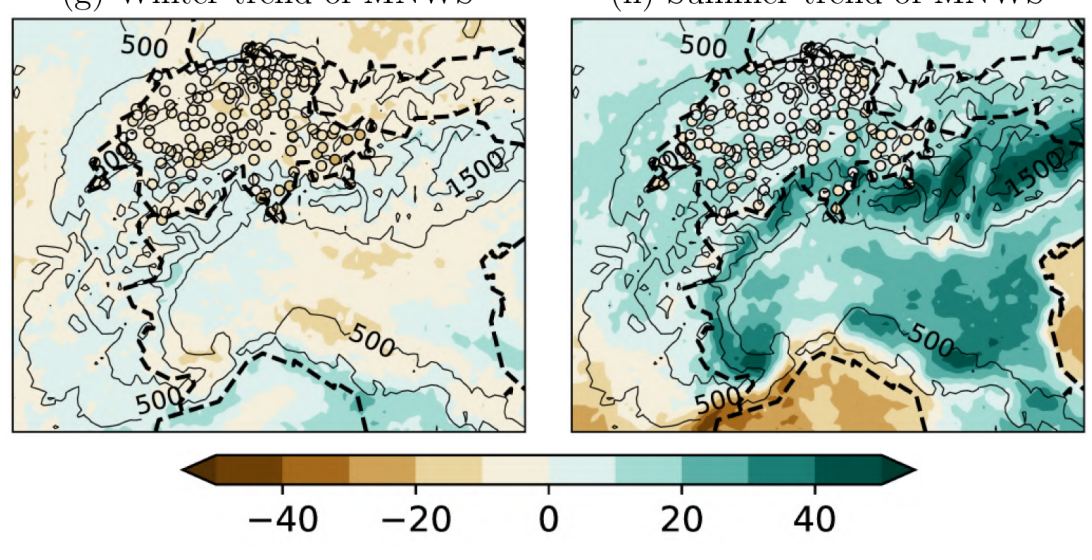

percent per century (b) Summer trend of WD

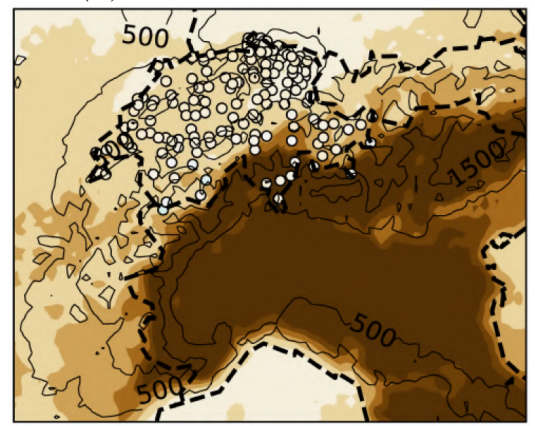

(d) Summer trend of SDII

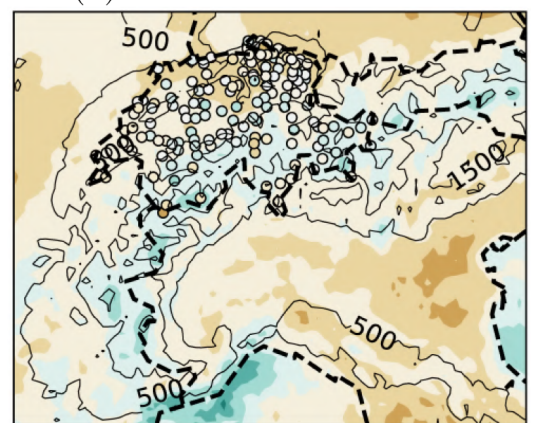

(f) Summer trend of MWSD

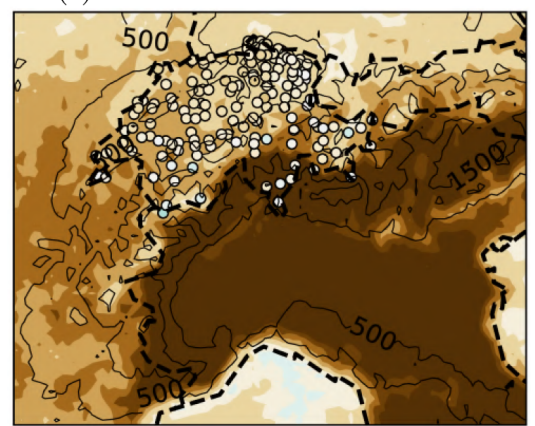

(h) Summer trend of MNWS

Figure 6. Winter and Summer 1903-2010 trends (\% per century) of WD (a, b), SDII (c, d), MWSD (e, f) and MNWS (g, h) simulated by MAR (shaded) and locally observed in Switzerland (dots). WD is computed as a percentage of the available daily data for observations. Any station from the observational network that includes missing data is excluded when computing the trends. 
(a) Winter maximum mean

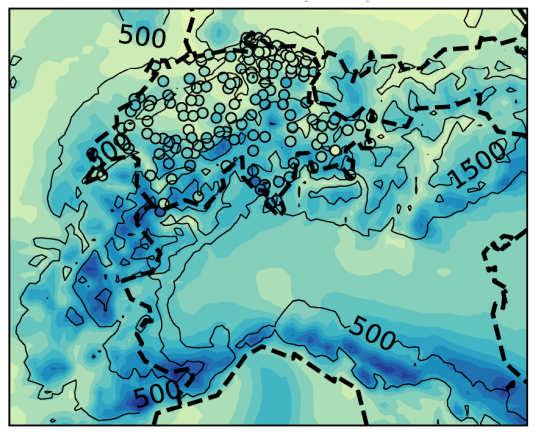

(c) Spring maximum mean

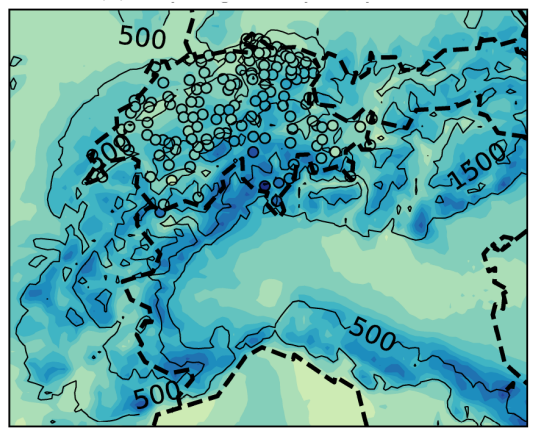

(e) Summer maximum mean

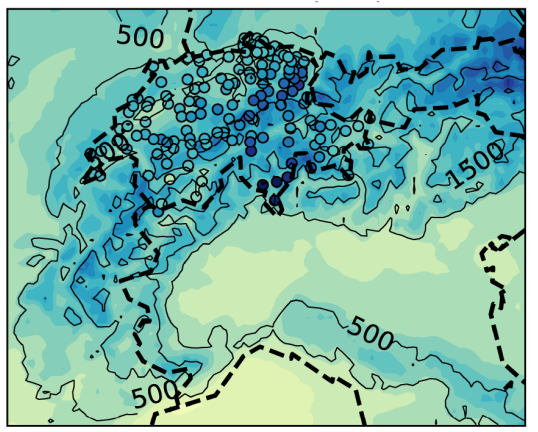

(g) Autumn maximum mean

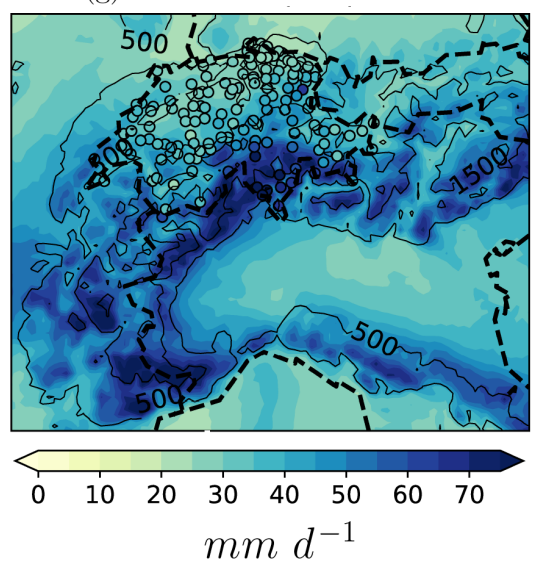

(b) Winter maximum trend

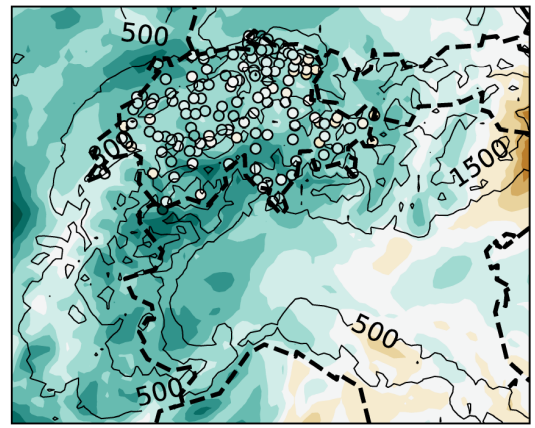

(d) Spring maximum trend

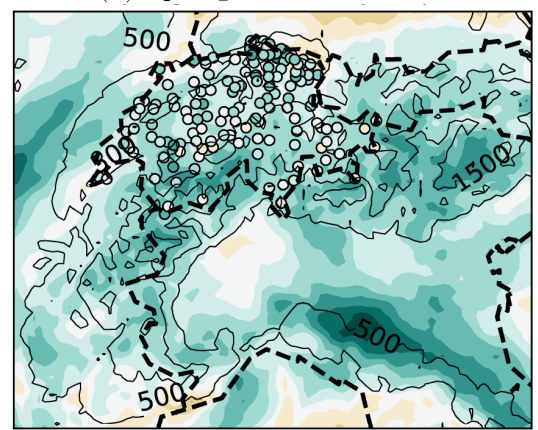

(f) Summer maximum trend

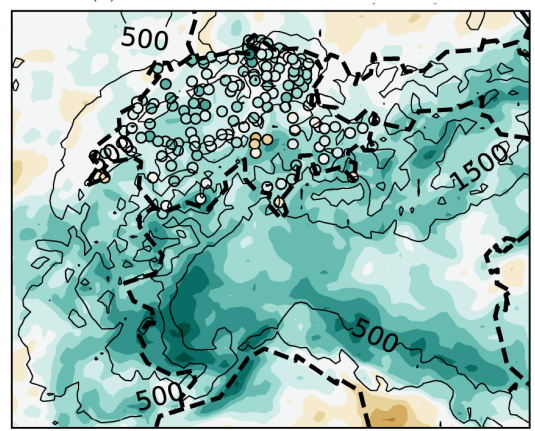

(h) Autumn maximum trend

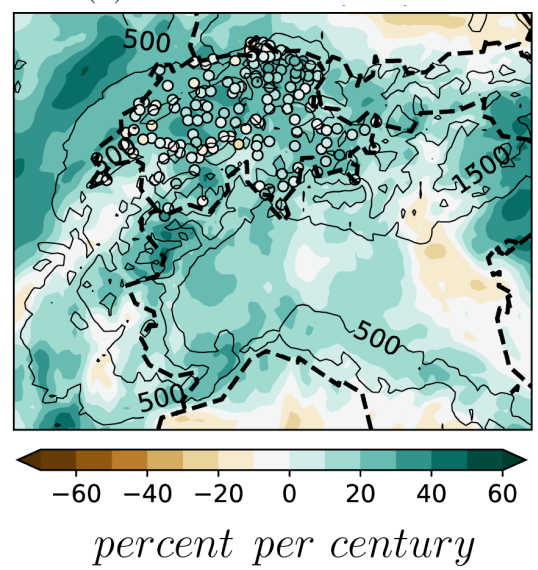

Figure 7. Seasonal mean ( $\left.\mathrm{mm} \mathrm{d}^{-1}, \mathbf{a}, \mathbf{c}, \mathbf{e}, \mathbf{g}\right)$ and trends (\% per century, b, d, f, h) over the period 1903-2010 of the seasonal Rx1day simulated by MAR (shaded) and locally observed in Switzerland (dots) for Winter (a, b), Spring (c, d), Summer (e, f) and Autumn (g, h). 
(a) Annual daily maximum mean

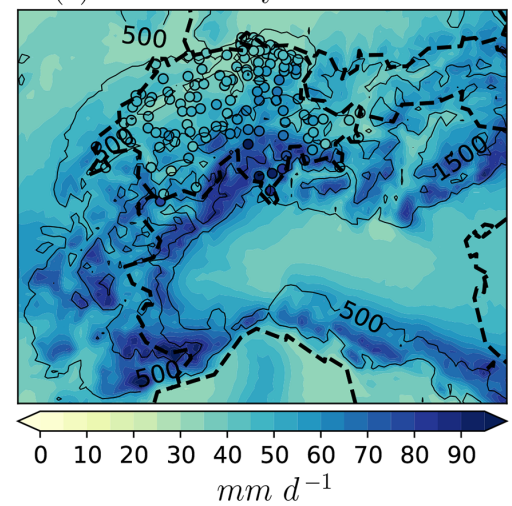

(c) Annual trend of the maximum

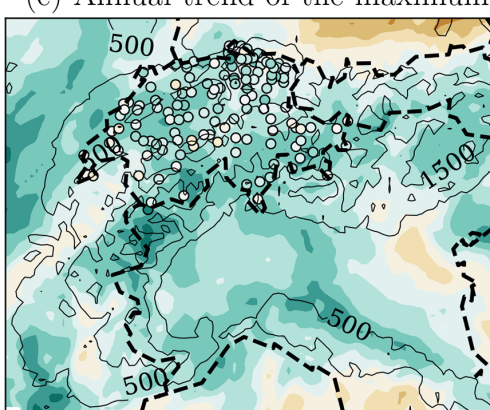

(b) Daily maximum over 1903-2010

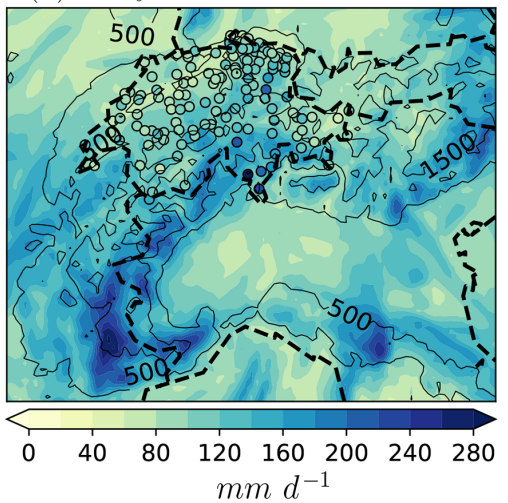

(d) Annual trend, non signif masked

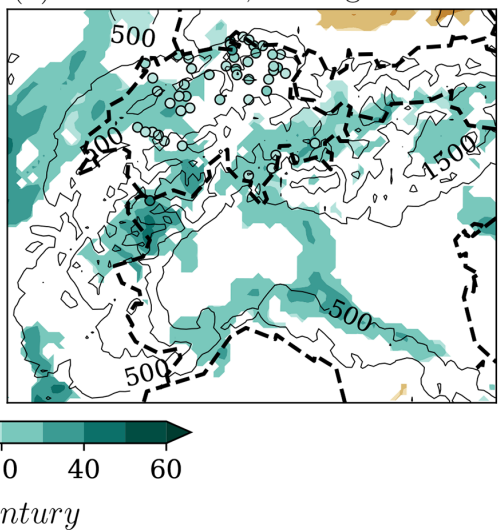

(f) $\mathrm{p}$ value of the linear trend
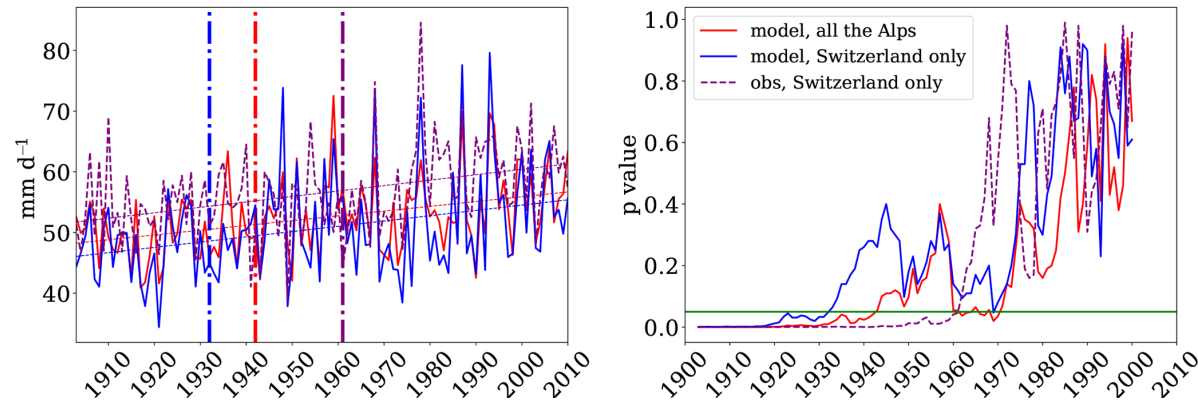

Figure 8. Mean (a) and maximum (b) of the annual Rx1day ( $\left.\mathrm{mm} \mathrm{d}^{-1}\right)$ and its trend (\% per century) including (c) and excluding (d) the areas where the $p$ value is lower than 0.05, over 1903-2010. Annual Rx1day (e) and associated $p$ value of the trend (f) over the same period averaged over the model domain (red for the entire Alpine region and blue for the Swiss domain only) and for the MeteoSwiss network (purple, average of the MeteoSwiss data station available over 1903-2010). The vertical bars in (e) highlight the year before which the $p$ value never exceeds 0.05 .

$7 \%{ }^{\circ} \mathrm{C}^{-1}$ (Trenberth et al., 2003). It is also smaller than the value of $7.7 \%{ }^{\circ} \mathrm{C}^{-1}$ reported by Scherrer et al. (2016) using meteorological stations available in Switzerland over the last century. The increase in Rx1day intensity shows a strong spatial variability, with values ranging between $0 \%$ and $40 \%$ in the MAR simulation (Fig. 8a). Also, it occurred during all the seasons (Fig. 7), even when the seasonal mean of precipitation is decreasing (Fig. 4).

An analysis of the relationship between temperature and strong precipitation is provided in Fig. 9 by superimposing the areas where the increase in annual Rx1day is positive and significant (Fig. 9a) with other variables (hatching areas for Rx1day signal superimposed to other variables in Fig. 9bf). The increase in Rxlday intensity is simulated both in areas with a strong warming (e.g. Apennines) or a moderate one (e.g. over the Alps at high elevation; Fig. 9b). The temperature change during Rxlday is positive and strong in the Apennines in the western and northeastern parts of the Italian Alps (up to $4{ }^{\circ} \mathrm{C}$ per century), whereas it shows smaller variations in the northern flank of the Alps and even negative 
(a) Trend of Rx1day

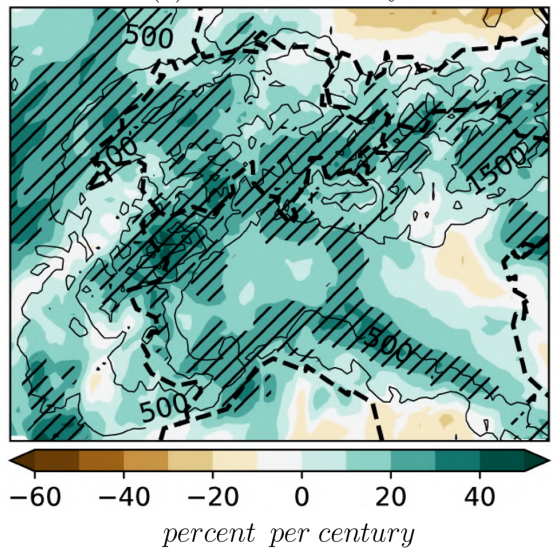

(c) Temperature trend during the Rx1day

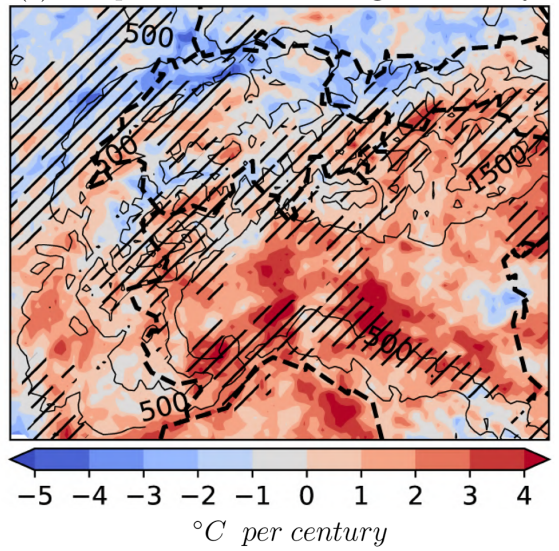

(e) Mean index day of Rx1day

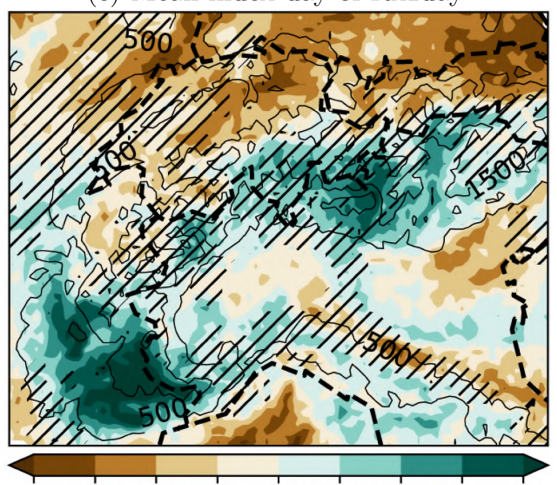

180190200210220230240250260

day (b) Trend of temperature

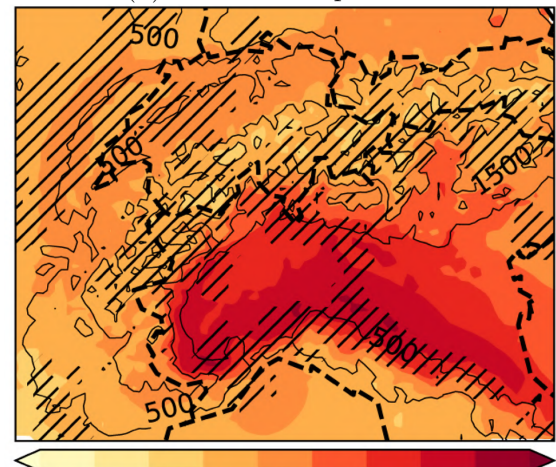

$\begin{array}{lllllllllll}0.0 & 0.2 & 0.4 & 0.6 & 0.8 & 1.0 & 1.2 & 1.4 & 1.6 & 1.8\end{array}$

${ }^{\circ} \mathrm{C}$ per century

(d) Rx1day correlation with annual temperature

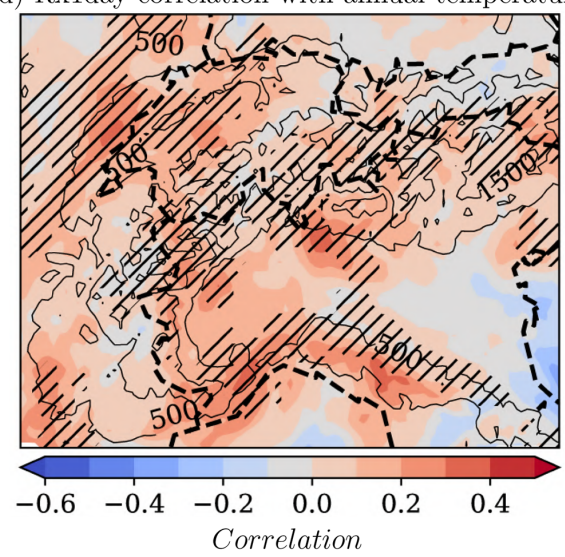

(f) Trend of the index day of Rx1day

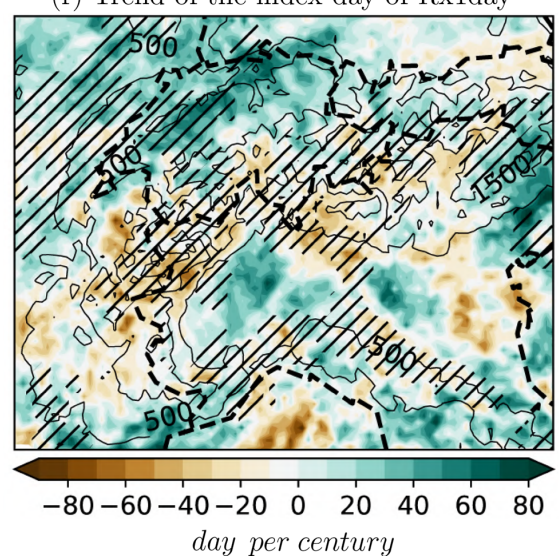

Figure 9. Rx1day intensity trend (a), temperature trend (b), temperature trend during the Rx1day occurrence (c) and correlation between Rx1day and annual temperature (d). Mean (e) and trend (f) of the occurrence day of Rx1day over 1903-2010. In all the panels, the hatching highlights the areas where the Rx1day trend is positive and significant ( $p$ value $<0.05$ ). Temperature increase and change in the convective versus total precipitation ratio are significant $(p$ value $<0.05)$ everywhere, whereas the trend (f) of the occurrence day of Rx1day is not significant ( $p$ value $>0.05)$. 
trends over the Jura (up to $-4{ }^{\circ} \mathrm{C}$ per century, Fig. 9c). Nevertheless, the increase in the Rx1day intensity projects well onto the pattern correlation between Rx1day and the annual temperature (Fig. 9d). These findings suggest that warmer temperatures favour strong precipitation events at the annual timescale, but the lack of correlation between the trends in Rx1day and the trends in temperature (Fig. 9b) at the local scale demonstrates that other processes than temperature changes affect Rx1day intensity. One of them is the shift in the seasonality of the occurrence of Rx1day. As shown in Fig. 9e, Rx1day occurs, on average, over 1902-2010, from July over the northern flank of the Alps (day 180 to 210) to August-September (day 210 to 270) over the southern flank of the Alps. In the Jura, the increase in Rx1day intensity is associated with a Rx1day shift from the summer to the autumn ( +30 to +60 d, Fig. 9f). This explains the small and even negative centennial trend of temperature during Rx1day in this area (Fig. 9c). Conversely, the strong warming occurring in the southeastern flank of the Alps and over the Apennine is not associated with any clear change in the seasonality of Rx1day (Fig. 9f). Over Switzerland, Brönnimann et al. (2018) also suggested a shift in the seasonality of Rx1day. A similar finding is found here, but caution is required with this assumption since the shifts described in Fig. 9f are not significant ( $p$ value $>0.05$ ). Rx1day positive trends are also simulated in areas with both limited warming and without any shift in the seasonality of Rx1day occurrence and in particular in the Alps at high elevation (Fig. 9f). This suggests that other processes are probably at play, driving increases in Rx1day intensity.

\section{Discussions and conclusions}

Previous work highlighted a temperature increase in the Alps over the last century, associated with an increase in precipitation over the northern Alps in winter and a drying in summer (Schmidli et al., 2002; Auer et al., 2007; Masson and Frei, 2014, 2016; Brugnara and Maugeri, 2019; Pavan et al., 2019). However, the detailed features of climate change over the Alps remain partly unknown, in particular because of the lack of observational data at high elevation and observational issues with snow precipitation. In addition, the large internal variability of the climate system, especially pronounced in Europe, may overwhelm long-term trends that remain challenging to detect. Here, MAR has been used at a $7 \mathrm{~km}$ resolution over the Alps over the period 1900-2010 and laterally forced with the ERA-20C reanalysis. A comparison with several datasets (EURO4M, SPAZM, S2M, E-OBS, HISTALP and local MeteoSwiss data) demonstrates that the model is able to reproduce the climatological precipitation rates as well as both the interannual variability and the seasonal cycle of precipitation over the Alps. The high resolution used in the MAR experiment allowed for a relatively correct representation of the topography, with a large number of grid cells covering elevations between 2000 and $3500 \mathrm{~m}$, corresponding to areas with few available observations. The vertical gradient of precipitation averaged over the Alpine area is estimated to be $33 \% \mathrm{~km}^{-1}\left(1.21 \mathrm{~mm} \mathrm{~d}^{-1} \mathrm{~km}^{-1}\right)$ in summer and $38 \% \mathrm{~km}^{-1}\left(1.15 \mathrm{~mm} \mathrm{~d}^{-1} \mathrm{~km}^{-1}\right)$ in winter, with values stronger in the northern Alps than in the southern Alps. The spatial variability of this vertical gradient is large, being affected by the local climate conditions.

The seasonal changes in precipitation simulated with MAR are largely related to changes in moisture fluxes found in the ERA-20C reanalysis at the European scale. The model experiment confirms an increase in precipitation during the winter over the northwestern Alps, above 500 m a.s.l., and significant and more pronounced above $1500 \mathrm{~m}$ a.s.l., with local values of $20 \%$ to $30 \%$ per century over the period 1903-2010. This increase in precipitation is mainly explained by more-intense precipitation during wet days, and it is associated with longer albeit less-frequent wet spells, a result consistent with Schmidli and Frei (2005) over Switzerland. The model reproduces the general drying that occurred in summer during the same period, exceeding $40 \%$ to $50 \%$ per century in the lowlands, whereas it is much smaller (< $10 \%$ per century) and not significant above $1500 \mathrm{~m}$ a.s.l. This drying is not related to a decrease in the intensity of precipitation, but it is explained by a drastic reduction in the number of wet days, with shorter and more-frequent wet spells. It is consistent with previous work suggesting that the Alpine region appears as an exception in a drying region, where convective precipitation increases locally, in relation to surface warming and sufficient moisture available in the soil at highelevation areas (Giorgi et al., 2016). The precipitation trends diagnosed over the last decades (i.e. from $\sim 1960$ ) differ from those described from the beginning of the 20th century. In particular, a strong moistening, albeit not significant, is found in autumn over most of the Alpine areas during the last decades and not over the last century. Furthermore, the drying of the Po plain is more pronounced and extended northward and westward during the winter, without a clear positive trend of precipitation at high elevation over the last decades during this season. The trends simulated over the last decades are consistent with recent studies based on observations covering the last decades (e.g. Isotta et al., 2014; Pavan et al., 2019).

The model reproduces the observed climatological patterns of the seasonal maximum precipitation and in particular the large values occurring in the southern Alps in autumn, exceeding 50 and even $70 \mathrm{~mm} \mathrm{~d}^{-1}$ on average over the period 1903-2010. This result is consistent with the radar observations described in Panziera et al. (2018), showing that the annual maximum of daily precipitation rates occurs during the autumn, whereas the annual maximum of hourly precipitation occurs preferentially during the summer in relation to convective events. Centennial daily events reaching 250 to $300 \mathrm{~mm} \mathrm{~d}^{-1}$ are simulated in the southern Alps, both in France and in Italy, as well as in the Ticino valley. The 
seasonal maximum of precipitation shows a general increase over the last century and during the four seasons, reaching values between $20 \%$ and $40 \%$ per century in the Alps. An increase in strong precipitation has been evidenced in previous studies over the European Alps in relation to higher temperature and moisture rates in the atmosphere following the Clausius-Clapeyron relationship (e.g. Ban et al., 2015). A significant relationship between Rx1day intensity and warming is also simulated over the Alps but with a smaller value reaching $3.11 \%{ }^{\circ} \mathrm{C}^{-1}$. This relationship shows a strong spatial variability in the MAR experiment, suggesting that other processes can affect Rx1day changes. On one side, the drying of the surface may act as a positive feedback enhancing warming signals, which has been identified as one of the causes of the Mediterranean amplification (Brogli et al., 2019). On the other hand, even with strong warming levels in place, Brönnimann et al. (2018) suggested a limited increase in Rxlday during the summer in the Alps due to moisture limitation. In their study, they pointed out a shift in this index typically observed at the end of the summer toward early summer and early autumn. Albeit not significant, shifts of seasonality of Rx1day are also found in the MAR experiment, which complicates the relationship between temperature and Rx1day. Nevertheless, the MAR experiment shows an increase in Rx1day both annually and for all seasons, and it is significant mainly over mountainous areas, a result consistent with the observations from Scherrer et al. (2016) and Brugnara et al. (2019). Further investigations are required to disentangle the different processes driving Rx1day changes and in particular the moisture availability in both the soil and the atmosphere at different layers. Following Doutreloup et al. (2019), who tested different convective schemes to simulate precipitation with MAR, dedicated experiments based on different resolutions, including smaller ones to allow for the resolution of convective processes, could help to understand how strong precipitation events are affected by changes in convective precipitation, in particular for strong local events that cannot be simulated with the intermediate resolution used in this study.
In the MAR experiments, the trends of the seasonal maxima of precipitation integrated over the Alps are significant ( $p$ value $<0.05$ ) only when considering long time series, typically 50 to 80 years depending on the area considered. Some of these trends are nonetheless significant when computed over recent decades, from the $1960 \mathrm{~s} / 1970$ s to the $2000 \mathrm{~s}$. This suggests a recent acceleration of the increase in extreme precipitation, whereas earlier periods with strong precipitation also occurred, in particular during the 1950s/1960s. These ones could be explained by internal climate variability and/or the non-linear response of the climate system to anthropogenic greenhouse gases and aerosols. In particular, the cooling related to aerosol forcing, which peaked during the 1970s/1980s (Koch et al., 2011) over Europe, could have masked the warming related to greenhouse gases and temporarily prevented changes in extreme precipitation. Further model investigations should be conducted to disentangle the variability of the Alpine climate related to internal variability and external forcings. This research is needed to anticipate possibly strong precipitation changes in the Alps under global climate change. 


\section{Appendix A}
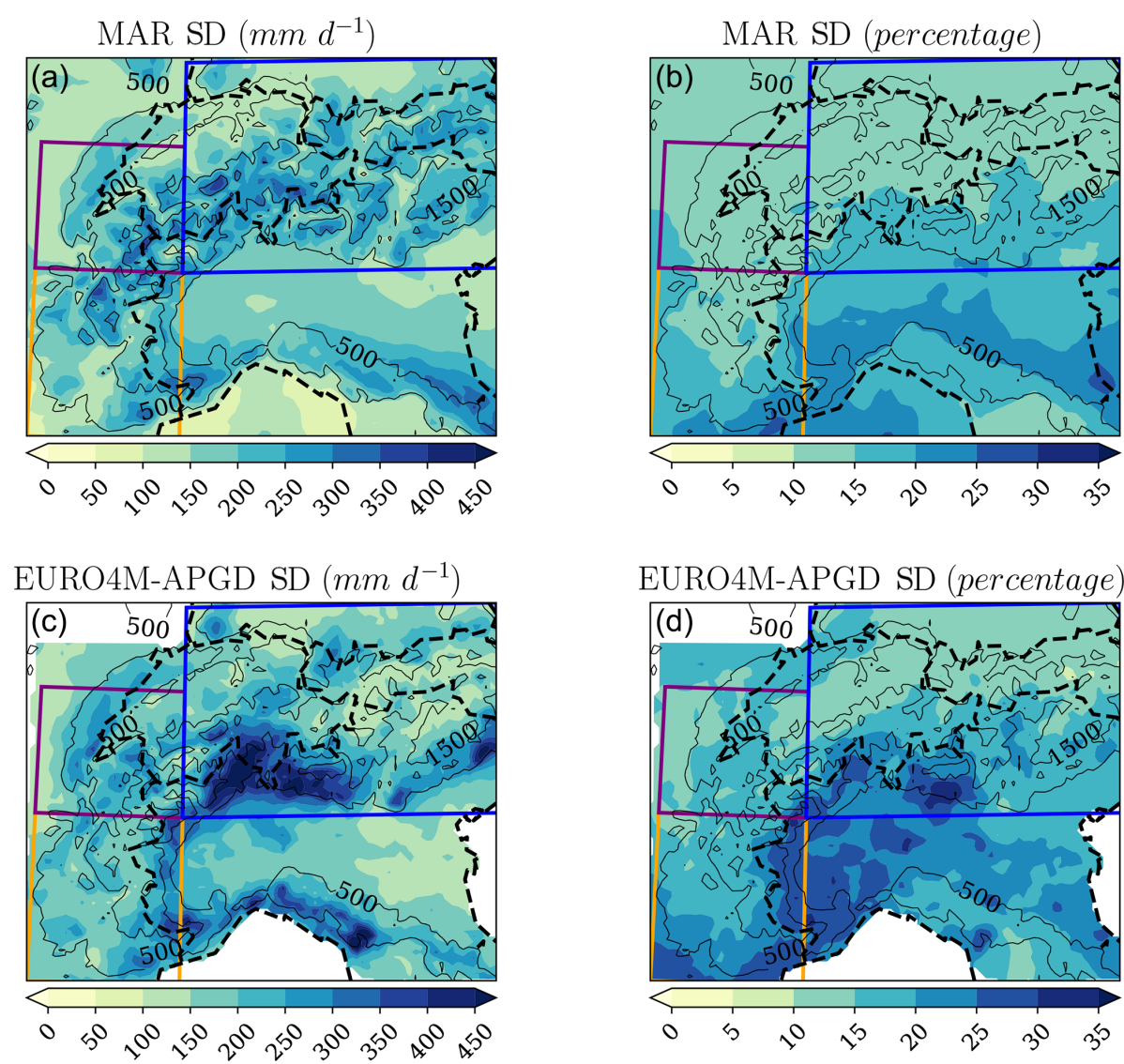

Figure A1. Standard deviation of annual precipitation over 1971-2008 (in $\mathrm{mm} \mathrm{d}^{-1}$ ) (a, c) and (in \%) (b, d) in the MAR experiment (a, b) and in the EURO4M-APGD dataset $(\mathbf{c}, \mathbf{d})$. 
Data availability. MAR is accessible at https://gitlab.com/ Mar-Group (last access: 12 November 2020) (GitLab, 2020) and documented at http://mar.cnrs.fr/ (last access: 12 November 2020) (MAR, 2020). The outputs of the MAR experiment used in this study can be downloaded at https://doi.org/10.5281/zenodo.3674607 (Ménégoz et al., 2020). The HISTALP data are available at http://www.zamg.ac.at/histalp/ (last access: 12 November 2020) (Auer et al., 2007). Alpine Precipitation Grid Dataset (EURO4M-APGD), Version 1, is available online at https://doi.org/10.18751/Climate/Griddata/APGD/1.0 (Isotta et al., 2014). ECA\&D data can be downloaded at https://www.ecad.eu//download/ensembles/ensembles.php (last access: 12 November 2020) (Cornes et al., 2018). S2M data are available online on the AERIS platform at https://doi.org/10.25326/37 (Vernay et al., 2019). The SPAZM dataset has been provided by EDF and Météo-France for this research. It could be made available to other researchers under a specific research agreement. Requests should be sent to dtg-demandedonnees-hydro@edf.fr.

Author contributions. All authors contributed to design the study. $\mathrm{XF}, \mathrm{MM}$ and JB ran MAR experiments and produced the figures. MM wrote the article and other authors contributed with suggested changes and comments.

Competing interests. The authors declare that they have no conflict of interest.

Acknowledgements. The authors thank the providers of observational datasets. The figures have been produced with the python package basemap (https://matplotlib.org/basemap/, last access: 12 November 2020). The authors thank the three referees for their useful comments and the editor for the efficient management of the review process.

Financial support. As part of the project CDP TRAJECTORIES, this work is funded by the French National Research Agency in the framework of the "Investissements d'avenir" programme (ANR-15IDEX-02). The training period of Evgenia Valla was funded by the ERASMUS programme and the VATEX project funded under the programme Labex OSUG@2020 (ANR10 LABX56). The authors thank the "Institut du Développement et des ressources en Informatique scientifique" (IDRIS, CNRS, project no. A0080101523) and the GRICAD project (https://gricad.univ-grenoble-alpes.fr/, last access: 12 November 2020) for providing computer time for the simulations presented in this paper.

Review statement. This paper was edited by Nadav Peleg and reviewed by Federico Grazzini and two anonymous referees.

\section{References}

Agosta, C., Amory, C., Kittel, C., Orsi, A., Favier, V., Gallée, H., van den Broeke, M. R., Lenaerts, J. T. M., van Wessem, J. M., van de Berg, W. J., and Fettweis, X.: Estimation of the Antarctic surface mass balance using the regional climate model MAR (1979-2015) and identification of dominant processes, The Cryosphere, 13, 281-296, https://doi.org/10.5194/tc13-281-2019, 2019.

Amory, C., Trouvilliez, A., Gallée, H., Favier, V., Naaim-Bouvet, F., Genthon, C., Agosta, C., Piard, L., and Bellot, H.: Comparison between observed and simulated aeolian snow mass fluxes in Adélie Land, East Antarctica, The Cryosphere, 9, 1373-1383, https://doi.org/10.5194/tc-9-1373-2015, 2015.

Auer, I. and Böhm, R.: Combined temperature-precipitation variations in Austria during the instrumental period, Theor. Appl. Climatol., 49, 161-174, 1994.

Auer, I., Böhm, R., Jurkovic, A., Lipa, W., Orlik, A., Potzmann, R., Schöner, W., Ungersböck, M., Matulla, C., Briffa, K., and Jones, P.: HISTALP - historical instrumental climatological surface time series of the Greater Alpine Region, Int. J. Climatol., 27, 17-46, 2007.

Ban, N., Schmidli, J., and Schär, C.: Evaluation of the convectionresolving regional climate modeling approach in decadelong simulations, J. Geophys. Res.-Atmos, 119, 7889-7907, https://doi.org/10.1002/2014JD021478, 2014.

Ban, N., Schmidli, J., and Schär, C.: Heavy precipitation in a changing climate: Does short-term summer precipitation increase faster?, Geophys. Res. Lett., 42, 1165-1172, 2015.

Bartolini, E., Claps, P., and D'Odorico, P.: Interannual variability of winter precipitation in the European Alps: relations with the North Atlantic Oscillation, Hydrol. Earth Syst. Sci., 13, 17-25, https://doi.org/10.5194/hess-13-17-2009, 2009.

Bechtold, P., Basile, E., Guichard, F., Mascart, P., and Richard, E.: A mass flux convection scheme for regional and global models, Q. J. Roy. Meteorol. Soc., 127, 869-886, 2001.

Beniston, M.: Mountain weather and climate: a general overview and a focus on climatic change in the Alps, Hydrobiologia, 562, 3-16, 2006.

Beniston, M., Farinotti, D., Stoffel, M., Andreassen, L. M., Coppola, E., Eckert, N., Fantini, A., Giacona, F., Hauck, C., Huss, M., Huwald, H., Lehning, M., López-Moreno, J.-I., Magnusson, J., Marty, C., Morán-Tejéda, E., Morin, S., Naaim, M., Provenzale, A., Rabatel, A., Six, D., Stötter, J., Strasser, U., Terzago, S., and Vincent, C.: The European mountain cryosphere: a review of its current state, trends, and future challenges, The Cryosphere, 12, 759-794, https://doi.org/10.5194/tc-12-759-2018, 2018.

Brogli, R., Kröner, N., Sørland, S. L., Lüthi, D., and Schär, C.: The Role of Hadley Circulation and Lapse-Rate Changes for the Future European Summer Climate, J. Climate, 32, 385-404, https://doi.org/10.1175/JCLI-D-18-0431.1, 2019.

Brönnimann, S., Rajczak, J., Fischer, E. M., Raible, C. C., Rohrer, M., and Schär, C.: Changing seasonality of moderate and extreme precipitation events in the Alps, Nat. Hazards Earth Syst. Sci., 18, 2047-2056, https://doi.org/10.5194/nhess18-2047-2018, 2018.

Brugnara, Y. and Maugeri, M.: Daily precipitation variability in the southern Alps since the late 19th century, Int. J. Climatol., 39, 3492-3504, https://doi.org/10.1002/joc.6034, 2019. 
Brun, E., David, P., Sudul, M., and Brunot, G., A numerical model to simulate snow-cover stratigraphy for operational avalanche forecasting, J. Glaciol., 38, 13-22, https://doi.org/10.3189/S0022143000009552, 1992.

Brunetti, M., Lentini, G., Maugeri, M., Nanni, T., Auer, I., Boehm, R., and Schoener, W.: Climate variability and change in the Greater Alpine Region over the last two centuries based on multivariable analysis, Int. J. Climatol., 29, 2197-2225, 2009.

Cornes, R., van der Schrier, G., van den Besselaar, E. J. M. , and Jones, P. D.: An Ensemble Version of the E-OBS Temperature and Precipitation Datasets, J. Geophys. Res.-Atmos., 123, 93919409, https://doi.org/10.1029/2017JD028200, 2018.

Datta, R. T., Tedesco, M., Agosta, C., Fettweis, X., Kuipers Munneke, P., and van den Broeke, M. R.: Melting over the northeast Antarctic Peninsula (1999-2009): evaluation of a high-resolution regional climate model, The Cryosphere, 12, 2901-2922, https://doi.org/10.5194/tc-12-2901-2018, 2018.

Dee, D. P., Uppala, S. M., Simmons, A. J., Berrisford, P., Poli, P., Kobayashi, S., Andrae, U., Balmaseda, M. A., Balsamo, G., Bauer, D. P., and Bechtold, P.: The ERA-Interim reanalysis: Configuration and performance of the data assimilation system, Q. J. Roy. Meteorol. Soc., 137, 553-597, 2011.

Dell'Aquila, A., Mariotti, A., Bastin, S., Calmanti, S., Cavicchia, L., Deque, M., Djurdjevic, V., Dominguez, M., Gaertner, M., and Gualdi, S.: Evaluation of simulated decadal variations over the Euro-Mediterranean region from ENSEMBLES to MedCORDEX, Clim. Dynam., 51, 857-876, 2018.

De Ridder, K. and Schayes, G.: The IAGL land surface model, J. Appl. Meteorol., 36, 167-183, 1997.

Doutreloup, S., Wyard, C., Amory, C., Kittel, C., Erpicum, M., and Fettweis, X.: Sensitivity to Convective Schemes on Precipitation Simulated by the Regional Climate Model MAR over Belgium (1987-2017), Atmosphere, 10, 34, https://doi.org/10.3390/atmos10010034, 2019.

Douville, H. and Plazzotta, M.: Midlatitude summer drying: An underestimated threat in CMIP5 models?, Geophys. Res. Lett., 44, 9967-9975, 2017.

Durand, Y., Laternser, M., Giraud, G., Etchevers, P., Lesaffre, B., and Mérindol, L.: Reanalysis of $44 \mathrm{yr}$ of climate in the French Alps (1958-2002): methodology, model validation, climatology, and trends for air temperature and precipitation. J. Appl. Meteorol. Clim., 48, 429-449, 2009.

Efthymiadis, D., Jones, P. D., Briffa, K. R., Böhm, R., and Maugeri, M.: Influence of large-scale atmospheric circulation on climate variability in the Greater Alpine Region of Europe, J. Geophys. Res.-Atmos., 112, D12104, https://doi.org/10.1029/2006JD008021, 2007.

Evin, G., Wilhelm, B., and Jenny, J. P.: Flood hazard assessment of the Rhône River revisited with reconstructed discharges from lake sediments, Global Planet. Change, 172, 114-123, 2019.

Fantini, A., Raffaele, F., Torma, C., Bacer, S., Coppola, E., Giorgi, F., Ahrens, B., Dubois, C., Sanchez, E., and Verdecchia, M.: Assessment of multiple daily precipitation statistics in ERAInterim driven Med-CORDEX and EURO-CORDEX experiments against high resolution observations, Clim. Dynam., 51, 877-900, 2018.

Favier, V., Verfaillie, D., Berthier, E., Menegoz, M., Jomelli, V., Kay, J. E., Ducret, L., Malbéteau, Y., Brunstein, D., Gallée, H., and Park, Y. H.: Atmospheric drying as the main driver of dra- matic glacier wastage in the southern Indian Ocean, Sci. Rep., 6, 32396, https://doi.org/10.1038/srep32396, 2016.

Fettweis, X., Box, J. E., Agosta, C., Amory, C., Kittel, C., Lang, C., van As, D., Machguth, H., and Gallée, H.: Reconstructions of the 1900-2015 Greenland ice sheet surface mass balance using the regional climate MAR model, The Cryosphere, 11, 1015-1033, https://doi.org/10.5194/tc-11-1015-2017, 2017.

Gallee, H.: Simulation of the mesocyclonic activity in the Ross Sea, Antarctica, Mon. Weather Rev., 123, 2051-2069, 1995.

Gallée, H., Pettré, P., and Schayes, G.: Sudden cessation of katabatic winds in Adélie Land, Antarctica, J. Appl. Meteorol., 35, 1142 1152, 1996.

Gallée, H. and Schayes, G.: Development of a three-dimensional meso-gamma primitive equation model: katabatic winds simulation in the area of Terra Nova bay, Antarctica, Mon. Weather. Rev., 122, 671-685, 1994.

Gallée, H., Guyomarch, G., and Brun, E.: Impact of snowdrift on the Antarctic ice sheet surface mass balance: possible sensitivity to snow-surface properties, Bound.-Lay. Meteorol., 99, 1-19, 2001.

Gallée, H., Moufouma-Okia, W., Bechtold, P., Brasseur, O., Dupays, I., Marbaix, P., Messager, C., Ramel, R., and Lebel, T.: A high resolution simulation of a West African rainy season using a regional climate model, J. Geophys. Res., 109, D05108, https://doi.org/10.1029/2003JD004020, 2004.

Gallée, H., Peyaud, V., and Goodwin. I.: Simulation of the net snow accumulation along the Wilkes Land transect, Antarctica, with a regional climate model, Ann. Glaciol., 41, 17-22, 2005.

Gallée, H., Trouvilliez, A., Agosta, C., Genthon, C., Favier, V., and Naaim-Bouvet, F.: Transport of snow by the wind: A comparison between observations in Adélie Land, Antarctica, and simulations made with the regional climate model MAR, Bound.-Lay. Meteorol., 146, 133-147, 2013.

Giorgi, F. and Lionello, P.: Climate change projections for the Mediterranean region, Global Planet. Change, 63, 90-104, 2008.

Giorgi, F., Torma, C., Coppola, E., Ban, N., Schär, C., and Somot, S.: Enhanced summer convective rainfall at Alpine high elevations in response to climate warming, Nat. Geosci., 9, 584-589, 2016.

GitLab: Atmospheric Regional Model, available at: https://gitlab. com/Mar-Group, last access: 12 November 2020.

Gobiet, A., Kotlarski, S., Beniston, M., Heinrich, G., Rajczak, J., and Stoffel, M.: 21st century climate change in the European Alps - a review, Sci. Total Environ., 493, 1138-1151, 2014.

Gottardi, F., Obled, C., Gailhard, J., and Paquet, E.: Statistical reanalysis of precipitation fields based on ground network data and weather patterns: Application over French mountains, J. Hydrol., 432, 154-167, 2012.

Gouttevin, I., Turko, M., Branger, F., Leblois, E., and Sicart, J. E.: Amélioration de la modélisation hydrologique distribuée en conditions naturelles dans les Alpes, Internal report, Action Neige 2016-2017, Doctoral dissertation, irstea, 2017.

Guillod, B. P., Jones, R. G., Bowery, A., Haustein, K., Massey, N. R., Mitchell, D. M., Otto, F. E. L., Sparrow, S. N., Uhe, P., Wallom, D. C. H., Wilson, S., and Allen, M. R.: weather@ home 2: validation of an improved global-regional climate modelling system, Geosci. Model Dev., 10, 1849-1872, https://doi.org/10.5194/gmd-10-1849-2017, 2017.

Hersbach, H. and Dee, D.: ERA5 reanalysis is in production, ECMWF Newsletter 147, ECMWF, Reading, UK, 2016. 
HISTALP: Welcome to HISTALP!, available at: http://www.zamg. ac.at/histalp/, last access: 11 November 2020.

Hock, R., Rasul, G., Adler, C., Cáceres, B., Gruber, S., Hirabayashi, Y., Jackson, M., Kääb, A., Kang, S., Kutuzov, A., Milner, A., Molau, U., Morin, S., Orlove, B., and Steltzer, H.: High Mountain Areas, in: IPCC Special Report on the Ocean and Cryosphere in a Changing Climate, edited by: Pörtner, H.-O., Roberts, D. C., Masson-Delmotte, V., Zhai, P., Tignor, M., Poloczanska, E., Mintenbeck, K., Alegría, A., Nicolai, M., Okem, A., Petzold, J., Rama, B., and Weyer, N. M., available at: http://report. ipcc.ch/srocc/pdf/SROCC_FinalDraft_Chapter2.pdf (last access: 12 November 2020), 2019.

Hoerling, M., Eischeid, J., Perlwitz, J., Quan, X., Zhang, T., and Pegion, P.: On the increased frequency of Mediterranean drought, J. Climate, 25, 2146-2161, 2012.

Isotta, F. A., Frei, C., Weilguni, V., Perčec Tadić, M., Lassegues, P., Rudolf, B., Pavan, V., Cacciamani, C., Antolini, G., Ratto, S. M., and Munari, M.: The climate of daily precipitation in the Alps: development and analysis of a high-resolution grid dataset from pan-Alpine rain-gauge data, Int. J. Climatol., 34, 1657-1675, 2014.

Koch, D., Bauer, S. E., Del Genio, A., Faluvegi, G., McConnell, J. R., Menon, S., Miller, R. L., Rind, D., Ruedy, R., Schmidt, G. A., and Shindell, D.: Coupled aerosol-chemistry-climate twentieth-century transient model investigation: trends in shortlived species and climate responses, J. Climate, 24, 2693-2714, 2011.

Kochendorfer, J., Rasmussen, R., Wolff, M., Baker, B., Hall, M. E., Meyers, T., Landolt, S., Jachcik, A., Isaksen, K., Brækkan, R., and Leeper, R.: The quantification and correction of windinduced precipitation measurement errors, Hydrol. Earth Syst. Sci., 21, 1973-1989, https://doi.org/10.5194/hess-21-1973-2017, 2017.

Kuglitsch, F. G., Toreti, A., Xoplaki, E., Della-Marta, P. M., Zerefos, C. S., Türkeş, M., and Luterbacher, J.: Heat wave changes in the eastern Mediterranean since 1960, Geophys. Res. Lett., 37, L04802, https://doi.org/10.1029/2009GL041841, 2010.

Lang, C., Fettweis, X., and Erpicum, M.: Future climate and surface mass balance of Svalbard glaciers in an RCP8.5 climate scenario: a study with the regional climate model MAR forced by MIROC5, The Cryosphere, 9, 945-956, https://doi.org/10.5194/tc-9-945-2015, 2015.

Lefebre, F., Gallée, H., van Ypersele, J. P., and Greuell, W.: Modeling of snow and ice melt at ETH Camp (West Greenland): A study of surface albedo, J. Geophys. Res.-Atmos., 108, 4231, https://doi.org/10.1029/2001JD001160, 2003.

Lüthi, S., Ban, N., Kotlarski, S., Steger, C. R., Jonas, T., and Schär, C.: Projections of Alpine Snow-Cover in a High-Resolution Climate Simulation, Atmosphere, 10, 463, https://doi.org/10.3390/atmos10080463, 2019.

MAR: Modèle Atmosphérique Régional, available at: http://mar. cnrs.fr/, last access: 12 November 2020.

Mariotti, A., Pan, Y., Zeng, N., and Alessandri, A.: Long-term climate change in the Mediterranean region in the midst of decadal variability, Clim. Dynam., 44, 1437-1456, 2015.

Masson, D. and Frei, C.: Spatial analysis of precipitation in a high-mountain region: exploring methods with multi-scale topographic predictors and circulation types, Hydrol. Earth Syst.
Sci., 18, 4543-4563, https://doi.org/10.5194/hess-18-4543-2014, 2014.

Masson, D. and Frei, C.: Long-term variations and trends of mesoscale precipitation in the Alps: recalculation and update for 1901-2008, Int. J. Climatol., 36, 492-500, 2016.

Ménégoz, M., Gallée, H., and Jacobi, H. W.: Precipitation and snow cover in the Himalaya : from reanalysis to regional climate simulations, Hydrol. Earth Syst. Sci., 17, 3921-3936, https://doi.org/10.5194/hess-17-3921-2013, 2013.

Ménégoz, M., Fettweis, X., Belleflamme, A., and Beaumet, J.: Climate simulation over the European Alps for the period 19022010 produced with the model MAR (Version MAR_Alps_v0) [Data set], Hydrology and Earth System Sciences, Zenodo, https://doi.org/10.5281/zenodo.3674607, 2020.

Messager, C., Gallée, H., and Brasseur, O.: Precipitation sensitivity to regional SST in a regional climate simulation during the West African monsoon for two dry years, Clim. Dynam., 22, 249-266, https://doi.org/10.1007/s00382-003-0381-x, 2004.

Messager, C., Gallée, H., Brasseur, O., Cappelaere, B., Peugeot, C., Séguis, L., Vauclin, M., Ramel, R., Grasseau, G., Léger, L., and Girou, D: Influence of observed and RCM-simulated precipitation on the water discharge over the Sirba basin, Burkina Faso/Niger, Clim. Dynam., 27, 199-214, https://doi.org/10.1007/s00382-006-0131-y, 2006.

Molnar, P., Fatichi, S., Gaál, L., Szolgay, J., and Burlando, P.: Storm type effects on super Clausius-Clapeyron scaling of intense rainstorm properties with air temperature, Hydrol. Earth Syst. Sci., 19, 1753-1766, https://doi.org/10.5194/hess-19-17532015, 2015.

Morcrette, J.-J.: Assessment of the ECMWF Model Cloudiness and Surface Radiation Fields at the ARM SGP Site, Mon. Weather Rev., 130, 257-277, 2002.

Naithani, J., Gallée, H., and Schayes, G.: Marine air intrusion into the Adelie Land sector of East Antarctica: A study using the regional climate model (MAR), J. Geophys. Res.-Atmos., 107, 4124, https://doi.org/10.1029/2000JD000274, 2002.

Napoli, A., Crespi, A., Ragone, F., Maugeri, M., and Pasquero, C.: Variability of orographic enhancement of precipitation in the Alpine region, Scient. Rep., 9, 1-8, 2019.

Panziera, L., Gabella, M., Germann, U., and Martius, O.: A 12-year radar-based climatology of daily and sub-daily extreme precipitation over the Swiss Alps, Int. J. Climatol., 38, 3749-3769, 2018.

Pavan, V., Antolini, G., Barbiero, R., Berni, N., Brunier, F., Cacciamani, C., Cagnati, A., Cazzuli, O., Cicogna, A., De Luigi, C., and Di Carlo, E.: High resolution climate precipitation analysis for north-central Italy, 1961-2015, Clim. Dynam., 52, 3435-3453, 2019.

Peterson, T., Folland, C., Gruza, G., Hogg, W., Mokssit, A., and Plummer, N.: Report on the Activities of the Working Group on Climate Change Detection and Related Rapporteurs 1998-2001, Rep. WCDMP-47, WMO-TD 1071, WMO, Geneve, Switzerland, 143 pp., available at: http://etccdi.pacificclimate.org/list_ 27_indices.shtml (last access: 12 November 2020), 2001.

Picouet, C., Réanalyse de l'équivalent en eau de la couverture neigeuse : développement d'un modèle de neige au pixel. Partie 2: Structuration d'un modèle neige à l'échelle du pixel au droit des chroniques historiques SWE, Technical report EDF-LTHEAlcotra, 2012. 
Pieri, A. B., von Hardenberg, J., Parodi, A., and Provenzale, A.: Sensitivity of precipitation statistics to resolution, microphysics, and convective parameterization: A case study with the highresolution WRF climate model over Europe, J. Hydrometeorol., 16, 1857-1872, 2015.

Poli, P., Hersbach, H., Dee, D. P., Berrisford, P., Simmons, A. J., Vitart, F., Laloyaux, P., Tan, D. G., Peubey, C., Thépaut, J. N., and Trémolet, Y.: ERA-20C: An atmospheric reanalysis of the twentieth century, J. Climate, 29, 4083-4097, 2016.

Qasmi, S., Cassou, C., and Boé, J.: Teleconnection between Atlantic multidecadal variability and European temperature: Diversity and evaluation of the Coupled Model Intercomparison Project phase 5 models, Geophys. Res. Lett., 44, 11-140, 2017.

Raymond, F., Wilhelm, B., and Anquetin, S.: Is Precipitation the Main Trigger of Medium-Magnitude Floods in Large Alpine Catchments?, Water, 11, 2507, https://doi.org/10.3390/w11122507, 2019.

Rottler, E., Kormann, C., Francke, T., and Bronstert, A.: Elevationdependent warming in the Swiss Alps 1981-2017: Features, forcings and feedbacks, Int. J. Climatol., 39, 2556-2568, 2019.

Scherrer, S. C., Fischer, E. M., Posselt, R., Liniger, M. A., CrociMaspoli, M., and Knutti, R.: Emerging trends in heavy precipitation and hot temperature extremes in Switzerland, J. Geophys. Res.-Atmos., 121, 2626-2637, 2016.

Schmidli, J. and Frei, C.: Trends of heavy precipitation and wet and dry spells in Switzerland during the 20th century, Int. J. Climatol., 25, 753-771, 2005.

Schmidli, J., Schmutz, C., Frei, C., Wanner, H., and Schär, C.: Mesoscale precipitation variability in the region of the European Alps during the 20th century, Int. J. Climatol., 22, 1049-1074, 2002.

Smiatek, G., Kunstmann, H. and Senatore, A.: EURO-CORDEX regional climate model analysis for the Greater Alpine Region: Performance and expected future change, J. Geophys. Res.Atmos., 121, 7710-7728, 2016.

Steger, C., Kotlarski, S., Jonas, T., and Schär, C.: Alpine snow cover in a changing climate: A regional climate model perspective, Clim. Dynam., 41, 735-754, 2013.

Torma, C., Giorgi, F., and Coppola, E.: Added value of regional climate modeling over areas characterized by complex terrain Precipitation over the Alps, J. Geophys. Res.-Atmos., 120, 39573972, 2015.

Trenberth, K. E., Dai, A., Rasmussen, R. M., and Parsons, D. B.: The changing character of precipitation, B. Am. Meteorol. Soc., 84, 1205-1218, 2003.

Uppala, S. M., Kållberg, P. W., Simmons, A. J., Andrae, U., Bechtold, V. D. C., Fiorino, M., Gibson, J. K., Haseler, J., Hernandez, A., Kelly, G. A., and Li, X.: The ERA-40 re-analysis, Q. J. Roy. Meteorol. Soc., 131, 2961-3012, 2005.
Van den Besselaar, E. J., Haylock, M. R., Van der Schrier, G., and Klein Tank, A. M. G.: A European daily high-resolution observational gridded data set of sea level pressure, J. Geophys. Res.Atmos., 116, D11110, https://doi.org/10.1029/2010JD015468, 2011.

Verfaillie, D., Favier, V., Gallée, H., Fettweis, X., Agosta, C., and Jomelli, V.: Regional modeling of surface mass balance on the Cook Ice Cap, Kerguelen Islands $\left(49^{\circ} \mathrm{S} 69^{\circ} \mathrm{E}\right)$, Clim. Dynam., 53, 5909-5925, https://doi.org/10.1007/s00382-01904904-z, 2019.

Vernay, M., Lafaysse, M., Hagenmuller, P., Nheili, R., Verfaillie, D., and Morin, S.: The S2M meteorological and snow cover reanalysis in the French mountainous areas (1958-present), [Data set], AERIS, https://doi.org/10.25326/37, 2019.

Vionnet, V., Six, D., Auger, L., Dumont, M., Lafaysse, M., Quéno, L., Réveillet, M., Dombrowski Etchevers, I., Thibert, E., and Vincent, C., Sub-kilometer precipitation datasets for snowpack and glacier modeling in alpine terrain, Front. Earth Sci., 7, 182, https://doi.org/10.3389/feart.2019.00182, 2019.

Viviroli, D. and Weingartner, R.: "Water towers" - A global view of the hydrological importance of mountains, in: Mountains: sources of water, sources of knowledge, Springer, Dordrecht, 1520, 2008.

Viviroli, D., Kummu, M., Meybeck, M., Kallio, M., and Wada, Y.: Increasing dependence of lowland populations on mountain water resources, Nat. Sustain., 3, 917-928, https://doi.org/10.1038/s41893-020-0559-9, 2020.

Wanner, H., Rickli, R., Salvisberg, E., Schmutz, C., and Schüepp, M.: Global climate change and variability and its influence on alpine climate - concepts and observations, Theor. Appl. Climatol., 58, 221-243, 1997.

Wyard, C., Scholzen, C., Fettweis, X., Van Campenhout, J., and François, L.: Decrease in climatic conditions favouring floods in the south-east of Belgium over 1959-2010 using the regional climate model MAR, Int. J. Climatol., 37, 2782-2796, 2017.

Wyard, C., Doutreloup, S., Belleflamme, A., Wild, M., and Fettweis, X.: Global Radiative Flux and Cloudiness Variability for the Period 1959-2010 in Belgium: A Comparison between Reanalyses and the Regional Climate Model MAR, Atmosphere, 9, 262, https://doi.org/10.3390/atmos9070262, 2018.

Zubler, E. M., Fischer, A. M., Fröb, F., and Liniger, M. A.: Climate change signals of CMIP5 general circulation models over the Alps - impact of model selection, Int. J. Climatol., 36, 30883104, 2016. 